\title{
Shoreface migrations at the shelf edge and sea-level changes around the Last Glacial Maximum (Gulf of Lions, NW Mediterranean)
}

\author{
G. Jouet ${ }^{a},{ }^{,}{ }^{\star}$, S. Bernéa ${ }^{a}$, M. Rabineau ${ }^{b}$, M.A. Bassetti ${ }^{a}$, P. Bernier ${ }^{c}$, B. Dennielou ${ }^{a}$, \\ F.J. Sierro ${ }^{d}$, J.A. Flores ${ }^{d}$ and M. Taviani ${ }^{\mathrm{e}}$
}

${ }^{a}$ Géosciences Marines, IFREMER, BP 70, Plouzané, France

${ }^{\mathrm{b}}$ UMR-CNRS 6538 Domaines Océaniques, I.U.E.M., Plouzané, France

c UMR-CNRS 5125 Paléoenvironnements et Paléobiosphère, Université C. Bernard Lyon1, Villeurbanne, France

'Universidad de Salamanca, Departamento de Geología, Salamanca, Spain

e ISMAR-CNR, Via P. Gobetti, 101 Bologna, Italy

*: Corresponding author : gjouet@ifremer.fr

\begin{abstract}
:
The Bourcart-Hérault canyon interfluve in the Gulf of Lions (NW Mediterranean) was the site of very high sedimentation (up to $2.5 \mathrm{~m} / \mathrm{kyr}$ ) around the Last Glacial Maximum, due to the vicinity of major fluvial systems that fed the shelf edge. Shoreface deposits and offshore muds deposited during each glacial/interglacial $100 \mathrm{kyr}$-cycle, created a repeated motif with high-angle and low-angle clinoforms on seismic profiles. New detailed morphological, sedimentological and paleo-environmental data, constrained by ${ }^{14} \mathrm{C}$ dating, allow us to propose a scenario for the evolution of this critical area between 46 and $15 \mathrm{cal}$. kyr BP. The major seismic sequence (S5), formed as a forced regression during the overall sea-level fall between MIS-3 and MIS-2, can be sub-divided into several prograding units, which indicate that relative sea-level changes were punctuated by intervals of increased fall or slowdown, or even stillstand. Similarly, the onset of sea-level rise was marked by steps, during which wave-cut terraces formed, and can be tracked all around the Gulf of Lions. Three stillstands or slowdowns of sea-level change are identified and dated by deposits found at $90 \mathrm{~m}$ relative sea-level (21 cal. kyr BP), 110-115 m rsl (18-17 cal. kyr BP), and 98-105 m rsl (before $15.9 \mathrm{cal}$. kyr BP). Cementation of beach rocks, that now form eroded pinnacles culminating at $90 \mathrm{~m}$, occurred during the $21 \mathrm{kyr}$ stillstand. The position of relative sea-level during the maximum lowstand is not known, but should be deeper than $115 \mathrm{~m}$. Periods of increased northwesterly winds favoured transport of coarser sediment at the shelf edge, in relation with deep water cascading: this created a distinct sandy interval during the period of Heinrich event 2 (around 24 cal. kyr BP), at the origin of amplitude anomaly on very high-resolution seismic data. The increased sea-level rise, around $15 \mathrm{cal}$. kyr BP, resulted in an abrupt decrease of sedimentation.
\end{abstract}

Keywords: Last Glacial Maximum; relative sea-level; high-resolution sedimentary record; Western Mediterranean; Heinrich events 


\title{
Shoreface migrations at the shelf edge and sea-level changes around the Last Glacial Maximum (Gulf of Lions, NW Mediterranean)
}

\author{
G. Jouet $^{1,2, *}$, S. Berné ${ }^{1}$, M. Rabineau ${ }^{2}$, M.A. Bassetti ${ }^{1}$, P. Bernier ${ }^{3}$, \\ B. Dennielou ${ }^{1}$, F.J. Sierro ${ }^{4}$, J.A. Flores ${ }^{4}$ and M. Taviani ${ }^{5}$.
}

\footnotetext{
${ }^{1}$ Géosciences Marines, IFREMER, BP 70, Plouzané, France.

${ }^{2}$ UMR-CNRS 6538 Domaines Océaniques, I.U.E.M., Plouzané, France.

${ }^{3}$ UMR-CNRS 5125 Paléoenvironnements et Paléobiosphère, Université C Bernard Lyon1, Villeurbanne, France.

${ }^{4}$ Universidad de Salamanca, Departamento de Geología, Salamanca, Spain.

${ }^{5}$ ISMAR-CNR, Via P. Gobetti, 101 Bologna, Italy

* Corresponding author. E-mail address : gjouet@ifremer.fr ,Tel: +33 (0)2 98224819 or +33 (0)2 98498758 , Fax: +33 (0)2 98224570
}

\begin{abstract}
The Bourcart-Hérault canyon interfluve in the Gulf of Lions (NW Mediterranean) was the site of very high sedimentation (up to $2.5 \mathrm{~m} / \mathrm{kyr}$ ) around the Last Glacial Maximum, due to the vicinity of major fluvial systems that fed the shelf edge. Shoreface deposits and offshore muds deposited during each glacial/interglacial 100 kyr-cycle, created a repeated motif with highangle and low-angle clinoforms on seismic profiles. New detailed morphological, sedimentological and paleo-environmental data, constrained by ${ }^{14} \mathrm{C}$ dating, allow us to propose a scenario for the evolution of this critical area between 46 and 15 cal. kyr BP. The major seismic sequence (S5), formed as a forced regression during the overall sea-level fall between MIS-3 and MIS-2, can be sub-divided into several prograding units, which indicate that relative sea-level changes were punctuated by intervals of increased fall or slow-down, or even stillstand. Similarly, the onset of sea-level rise was marked by steps, during which wavecut terraces formed, and can be tracked all around the Gulf of Lions. Three stillstands or slowdowns of sea-level change are identified and dated by deposits found at $90 \mathrm{~m}$ relative sealevel (21 cal. kyr BP), 110-115 m rsl (18-17 cal. kyr BP), and 98-105 m rsl (before 15.9 cal. kyr BP). Cementation of beach rocks, that now form eroded pinnacles culminating at $90 \mathrm{~m}$, occurred during the $21 \mathrm{kyr}$ stillstand. The position of relative sea-level during the maximum lowstand is not known, but should be deeper than $115 \mathrm{~m}$. Periods of increased northwesterly winds favoured transport of coarser sediment at the shelf edge, in relation with deep water cascading: this created a distinct sandy interval during the period of Heinrich event 2 (around 24 cal. kyr BP), at the origin of amplitude anomaly on very high-resolution seismic data. The
\end{abstract}


increased sea-level rise, around 15 cal. kyr BP, resulted in an abrupt decrease of sedimentation.

Keywords: Last Glacial Maximum, relative sea-level, high-resolution sedimentary record, Western Mediterranean, Heinrich events.

\section{Introduction}

During the last two decades, a sub-continuous record of Quaternary paleoclimatic evolution has been obtained from marine and continental studies or ice cores. The important climatic changes, which were amplified since 900 kyr (MIS-22/23, Ruddiman et al., 1986; Thunell et al., 1991), led to dramatic variations in sea-level and oceanic circulation, sediment erosion and transport; these changes have had a major impact on the architecture and sedimentary environments of continental margins. The relative sea-level changes can be deduced from the oxygen isotope ratio $\left(\delta^{18} \mathrm{O}\right)$ of foraminifera (Imbrie et al., 1984; Martinson et al., 1987; Labeyrie, 1987, 1989; Shackleton, 2000; Waelbroeck at al., 2002), and the "isotopic" sealevel curves are constrained by coral reefs studies (Fairbanks, 1989; Chappell and Polach, 1991; Bard et al., 1990, 1996). Sea-level is, thus, inferred from species living only at a given water depth and their relative position with respect to the base level. Nevertheless, all of these methods have intrinsic uncertainties and there is a need of independent documentation of sealevel position. In this paper, a sea-level estimation method using a geological approach is presented, based on data collected in Western Mediterranean area.

The Gulf of Lions (Fig. 1) is a passive continental margin that is located far from main icesheets, with a relatively constant subsidence rate and a high sediment supply it therefore represents an ideal area for studying the impact of sea-level changes on sedimentary strata and sequences. The main sediment source is from the alpine glaciers and the Rhône watershed (100 $000 \mathrm{~km}^{2}$ ), with additional supply from the Pyrénées and Massif Central rivers (Aude, Agly, Tech, Têt, Orb and Hérault, in Fig. 1). The combination of high sedimentation supply and significant subsidence rate (250 m/Myr at the shelf edge, Rabineau, 2001) generates the progressive filling of available space, and the preservation of the depositional sequences at the shelf edge. It is thus well-documented that part of the remaining sediment supply is bypassed and feeds the prograding continental slope (Lofi et al., 2003), the Rhône deep sea fan (Droz and Bellaiche, 1985) and the Pyreneo-Languedocian sedimentary ridge (Berné et al., 1999). 
The objective of this paper is to investigate the architecture of prodeltaic/shoreface sediments deposited around the Last Glacial Maximum (between 46 and 15 cal. kyr BP) at the shelf edge, and to propose a scenario for sea-level oscillations during this period.

\section{Geological and environmental settings}

\subsection{Stratigraphic organisation of the Gulf of Lions continental margin}

The Palaeozoic and Mesozoic metamorphic basement of the Rhône margin (Biju-Duval, 1984) is covered by a Neogene to Quaternary sedimentary mega-sequence (Bentounsi, 1990; Gorini et al., 1993; Gueguen, 1995; Sioni, 1997). The margin was formed after a period of rifting during the Oligocene-Aquitanian, followed by deposition of thick Neogene sequences (see the review by Berné and Gorini, 2005). At the end of the Miocene, the Messinian salinity crisis (Hsü et al., 1973; Clauzon, 1974) represented a major event all over the Mediterranean: a sea-level drawdown led to a pronounced erosion surface on the margins and deposition of deep-basin evaporitic sequence. On the other hand, the Plio-Quaternary sedimentation was characterized by important margin progradation (about $70 \mathrm{~km}$ in about $5 \mathrm{Myr}$; Lofi et al., 2003). On the basis of recent seismic investigations, the upper Quaternary sequences are observed to show the stacking of several prograding wedges bounded by discontinuities (D30, D40, D50, D60 and D70 in Fig. 2) they converge in a landward direction, with a pinch out at about $80 \mathrm{~m}$ water depth. In detail, the prograding wedges display two major types of seismic facies: (1) PI prisms with gently dipping clinoforms $\left(<1^{\circ}\right)$, and (2) PII prisms with relatively high-angle clinoforms (from $3^{\circ}$ to $7^{\circ}$ ). This elementary motif (PI/PII) is repeated vertically and allowed to define 5 major sequences (S1 to S5; Rabineau et al., 2005) bounded by major discontinuities (Fig. 2). The regressive deposits represent the most significant element constituting outer shelf sequences, when in fact the transgressive deposits are limited to a thin veneer of reworked sands that top the regressive shoreface deposits (Berné et al, 1998; Bassetti et al., this volume). Some authors considered that each of these wedges corresponded to 100 kyr-glacio-eustatic cyles (Aloïsi, 1986; Rabineau, 2001), whereas others proposed that they were linked to higher-frequency (20-40 kyr) cyclicities (Tesson et al., 1993; Gensous et al., 1993; Tesson et al., 1994; Gensous and Tesson, 1996). Stratigraphic modelling supports the 100-kyr hypothesis because other explanations would imply unrealistic subsidence rates (Rabineau et al., 2005).

The present day morphology of the continental shelf clearly illustrates the effect of the lowest sea-level during glacial and the deglacial sea-level rise (Fig. 1) with (1) Pleistocene lowstand 
shoreface sands between about $80 \mathrm{~m}$ and $120 \mathrm{~m}$ water depth, (2) Pleistocene lowstand prodeltaic/lower shoreface muds beyond about $120 \mathrm{~m}$ water depth and (3) the deglacial (transgressive and highstand) littoral prism (Aloïsi et al., 1977) with prodeltaic muds (between about 20 and $80 \mathrm{~m}$ water depth) and shoreface sands (between the coastline and about $20 \mathrm{~m})$.

\subsection{Hydrodynamics}

The Gulf of Lions is a wave-dominated shelf with moderate energy. However, wave heights associated to SE winds can be in excess of $8 \mathrm{~m}$ with periods of about $10 \mathrm{~s}$. During winter, dominant $\mathrm{N}$ and NNW winds (Mistral and Tramontane) generate cascading of cold dense water with strong associated currents, especially in canyon heads situated to the SW of the Gulf of Lions (Palanques et al., this volume). The general circulation (Fig. 1) is mainly governed by the anti-clockwise flow of the Liguro-Provençal or Northern Current (Millot, 1990). This current roughly follows the shelf edge, but it locally deviates in relation with seafloor morphology, creating secondary anti-cyclonic gyres extending to the upper part of the canyons and sweeping the interfluves (Durrieu de Madron, 1992). The hydrodynamism on the platform is slightly modified and locally associated to the coastal wind and swell-induced currents (Millot, 1990, 1999).

\subsection{Climate and sea-level changes during the Last Glacial Cycle}

The Quaternary is characterized by cyclic climate and sea-level changes (Shackleton, 1987) that strongly impact the sedimentary architecture of continental margins. Within these Milankovitch cycles, more rapid fluctuations in $\delta^{18} \mathrm{O}$ have been identified at the millennial scale (Dansgaard et al., 1993); these Dansgaard-Oeschger oscillations (D/O) determine asymmetrical cycles with a progressive cooling at a regional scale followed-up by an abrupt increase of temperatures (Bond et al., 1993). The coldest intervals occur during Heinrich events (Ruddiman, 1977; Heinrich, 1988), approximately every 11 kyr (Bond et al., 1992). Even if the Mediterranean Sea lies far from the former ice sheets, these events are identified within Mediterranean sediments. For instance, in the Alboran Sea, Cacho et al. (1999) suggested that, during Heinrich events 1-5, polar waters reached the Mediterranean Sea through the Strait of Gibraltar and induced a weakening of the thermohaline circulation. The modelling of paleocirculation at the LGM (Myers et al., 1999) indicates a similar direction in the Liguro-Provençal current but certainly amplified by the low sea-level. Similarly, on the continent, the reduced evaporation and the strengthening of storms would lead to a decrease in 
precipitation and change in the hydrological cycle (Bartov et al., 2002). The low temperatures and a significant increase in wind intensity (Myers et al., 1999) resulted in enhanced wind erosion of the watershed during LGM (Ehlers, 1996). It has been proposed that the sedimentary flux, during the maximum of glaciation, was 3 to 3.5 times greater than the present one (Bossuet et al., 1996).

During the last glacial cycle, the Mediterranean Sea was connected to the global ocean and therefore followed the same trends for absolute sea-level changes (Fig. 3). The various isotopically-derived sea-level curves for the last 120 kyr (Labeyrie, 1987, 1989; Waelbroeck et al., 2002; Shackleton, 2000; Siddall et al., 2003) display a general fall until the LGM, punctuated by high-frequency changes; these sea-level curves have been constrained in depth by coral reefs studies (Bard et al., 1990, 1996; Fairbanks, 1989) and ice-cap volume estimations (Shackleton, 1977). However, differences in the order of $40 \mathrm{~m}$ remain between various data sets, as summarized in Fig. 3. And the last low sea-level (isotopic stage 2) is generally set around 110 and $120 \mathrm{~m}$ below present sea-level, but estimates going from 90 to 150 m were proposed (Shackleton, 1977; Fairbanks, 1989; Bard et al., 1990; Lambeck and Bard, 2000; Clark and Mix, 2002).

\section{Methods}

The study area was surveyed in great detail in preparation of a scientific drilling expedition as part of the European "PROMESS 1" project (Berné et al., 2004). The available data, acquired on board R/V "L'Atalante", R/V "Le Suroît" and R/V "L'Europe", include very precise swath bathymetric data from Simrad EM12D, EM300, and EM1000. Seismic data presented in this paper include Sparker and mud penetrator (Chirp) sources (Figs 1 and 4). The vertical resolution of the single-channel Sparker (700 Joules, 500 to $2000 \mathrm{~Hz}$ ) is around $1 \mathrm{~m}$, whereas that of the hull-mounted Chirp system of R/V "Le Suroît" (2000 to $5200 \mathrm{~Hz}$ system) is in the range of $50 \mathrm{~cm}$. A long impulse $(50 \mathrm{~ms})$ was linearly modulated in time and frequency (Schock et al., 1989). To improve the signal/noise ratio, the raw data were processed with the Ifremer SITHERE program (Lericolais et al., 1990). The interpretation of seismic profiles was implemented using the general principles of seismic stratigraphy (Mitchum et al., 1977).

Several piston cores, including the "giant" piston corer of R/V "Marion Dufresne", were retrieved from the study area, with penetration reaching more than $20 \mathrm{~m}$ in soft sediments or alternating sands and silts, but less than $3 \mathrm{~m}$ in massive sands, even with vibro-corers. These cores are located along a transect across the canyon interfluve (Fig. 4). Physical properties 
were first measured onboard using the MSCL-GEOTEK (Multi Sensor Core Logging system). They were split, described and sampled for multi-proxy studies. Radiometric dates were obtained with accelerator mass spectrometer (AMS) ${ }^{14} \mathrm{C}$ dating of well-preserved shells. AMS measurements were made at Lawrence Livermore National Laboratory (CAMS) and at Poznan Radiocarbon Laboratory (PRL) (Table.1). The ages reported herein are $\delta^{13} \mathrm{C}$ normalised conventional ${ }^{14} \mathrm{C}$ years, corrected for an assumed air-sea reservoir effect of -400 years, then converted into calibrated ages using the Cal. v4.4 version (Stuiver et al., 1998), and the Glacial polynomial (Bard et al., 1998).

\section{Results}

\subsection{Morphology of the study area}

The study area is located between 90 and $350 \mathrm{~m}$ water depth, in the vicinity of the Bourcart (Aude) and Hérault canyons (Fig. 4). Along the interfluve, the shelf break is positioned at 180 $\mathrm{m}$ depth, whereas it is only at about $110 \mathrm{~m}$ at the position of canyon heads. Both sides of the canyon interfluve are affected by slump scars. The smooth morphology of this region is disturbed by several pockmarks, often aligned along preferential direction.

\section{a) Shelf scarps}

Besides the shelf break, a major scarp, about $10 \mathrm{~m}$ high is observed in the study area. Its average slope is about $4^{\circ}$, compared to the average $0.13^{\circ}$ slope of the outer continental shelf. The top of the scarp is at a water depth of 110 to $115 \mathrm{~m}$, except in the vicinity of the Bourcart canyon, where it is at a depth of about $120 \mathrm{~m}$. Another step, best observed on seismic profiles (Fig. 7), has its top at a depth of 98 to $105 \mathrm{~m}$; these two steps can be observed throughout the Gulf of Lions (Berné et al., 2002; Fig. 1) at similar water depths.

These scarps correspond to the transition between two major sedimentary units:

- "relict offshore sands" that formed during the last glacial cycle forced regressions;

- offshore/prodeltaic muds that represent the distal (seaward) equivalent to the upper shoreface sands (Berné, 1999).

\section{b) Cemented sands}

Another striking morphological feature in the study area corresponds to an area of elongated relief parallel to bathymetric contour lines, culminating at $90 \pm 0.5 \mathrm{~m}$ water depth (based on very detailed swath bathymetric data), up to $20 \mathrm{~m}$ above the surrounding sea-floor (Fig. 5A). 
It has a lateral extent of more than $7 \mathrm{~km}$ and a width of about $300 \mathrm{~m}$. Seismic profiles (section 4.2) show that it tops the clinoforms of the upper shoreface sand facies, and that erosion occurred, particularly at the bottom of the landward flank of the relief. A sample was dredged at the top of this ridge and shows that it comprises coarse siliciclastic sands cemented by small crystals of high- magnesian calcite during early diagenetic processes. The grain fabric, the petrographic, and geochemical nature of the cement indicate that cementation occurred in the phreatic zone, with a slight influence of brackish water, thus implying a formation in the vicinity of the shoreline with possible lagoonal influence (Bernier, 2000). This observation rules out the possibility that these lithified sands could be gresified aeolian dunes as observed in the Eastern Mediterranean (Almagor, 1979) or on the South Florida margin (Locker et al., 1996). $\mathrm{A}{ }^{14} \mathrm{C}$ date of the cement extracted and separated from carbonates by density (in order to avoid contamination by carbonate fragments of biogenic or detritic origin) indicates a precise diagenetic age of cementation of $17,785 \pm 240{ }^{14} \mathrm{C}$ yr BP (21 cal. kyr BP). The presence of beach rocks above the shoreface sands, at $90 \mathrm{~m}$ below modern sea-level, can only be explained by erosion that would have removed up to $20 \mathrm{~m}$ of sediment. This estimate is confirmed by geotechnical measurements around other pinnacles, culminating at the same depth of $90 \mathrm{~m}$ and located to the East of the Hérault canyon; they indicate a maximum overconsolidation of muds underlying the eroded shoreface sands of about 30 m (Baztan, 2004)

\section{c) Fluvial network and canyon incisions}

A paleo-network of reliefs, attributed to the retreat path of streams during the deglacial sealevel rise, has already been described all over the continental shelf (Berné et al., 2002), and more specifically on the Bourcart-Hérault interfluve (Rabineau, 2001). The connection between canyon heads and streams during the Last Glacial Maximum is demonstrated by axial incisions within the Bourcart and Hérault-2 and Hérault-3 canyons (Baztan et al., 2005). In fact, the so-called Hérault canyon was connected during LGM to the Rhône, the Hérault being a tributary of the Rhône at that time (Berné et al., 2004); this major stream built a shelf edge delta that can be identified on the basis of bathymetric data, as showed in Fig. 4B (1). Similarly, another stream (Aude or Agly), flowing from the West, reached the western flank of the Bourcart canyon and was at the origin of axial incision within the canyon head (2 in Fig. 4B). Seismic data presented in section 4.2 indicate that a stream reached the interfluve and fed an eastern branch of the Bourcart canyon head (3 in Fig. 4B), but this is not observable on the present day morphology. 


\section{d) Dunes}

All the sandy deposits, interpreted as the result of deglacial and modern processes, are shaped by low amplitude (2-3 m) bedforms (dunes and sand ridges) with a main East-West long axis (Bassetti et al., this volume).

In summary, all information confirms that the study area was impacted by the outbuilding of a major deltaic/shoreface system during the last glacial period.

\subsection{Seismic architecture of the last glacial depositional sequence}

Within the last glacial seismic sequence (S5 in Fig. 2A), several sub-units can be identified thanks to the very dense seismic coverage of the high resolution, newly acquired Sparker and Chirp data (Figs 4, 6 and 7).

The basal unit (U147) displays sub-parallel, continuous and very gently dipping reflections, with alternating high and low amplitude reflection facies (Fig. 6). The lower boundary of U147 is the major erosional surface (D60) correlated at the regional scale (Fig. 2) and interpreted as the regressive surface of erosion that formed during Marine Isotope Stage 6 (Rabineau et al., 2005). The upper boundary (D63) is an erosional truncation in the proximal part of the interfluve, down to about $145 \mathrm{~m}$ below sea-level, and becomes conformable in the seaward direction (Fig. 7). Consequently, U147 thickens in the offshore direction. The amount of erosion can be estimated on the basis of the truncation of successive reflections up to $10 \mathrm{~m}$ in the upper part of the interfluve. The seaward migration of the offlap break within U147 and the erosion of the topsets in the landward portion suggest a general progradation of the depositional system (Figs 6 and 7).

The upward transition (from U147 to U151) is marked by a dramatic change in clinoform geometries with low angle clinoforms of U147 rapidly passing to high angle clinoforms of the upper sandy shoreface facies (Fig. 8).

Units U151 and U152 have similar seismic facies: they display quasi-parallel internal reflections with important lateral variations in seismic facies and they change from discontinuous wavy reflections in the proximal part (Fig. 7), becoming parallel and continuous in seaward direction. The wavy facies is similar to undulations observed on continental shelves and slopes, interpreted by many authors as bedforms (sediment waves: Migeon et al., 2001; Lee et al., 2002) or deformation structures evolving into depositional 
bedforms (Cattaneo et al., 2004). They have a spacing of about $300 \mathrm{~m}$, an average height of 1.5 to $2 \mathrm{~m}$ and with a thinning of the seaward dipping limb. U151 is mainly aggradational and the transition to U152 seems to be gradual. It is worth noting that similar bedforms are observed within older sequences, such as sequence S4 in Fig. 6 . The very weak slope $\left(<1^{\circ}\right)$ of these bedforms would prevent their recognition in the stratigraphic record.

U152 displays clear seaward migration of the offlap break (progradation). The seaward migration of the wavy facies illustrates this trend, as well as the progressive seaward shift of depocentres creating internal discontinuities within this unit (Fig. 7). The boundary between the two units is locally marked by high-amplitude reflections (D65).

In summary, the stacking pattern of U151 and U152 is characterized by a progressive change from aggradation to progradation of the low-angle clinoforms preserved along the interfluve (Fig. 7). The correlative high-angle reflection clinoforms of the sandy facies (PII) document about $7 \mathrm{~km}$ of shoreline progradation (Fig. 8). Despite erosion of the topsets, preservation of the bottomsets can aid estimate the clinoform geometry and does not indicate a major change in sea-level.

Unit U154 is the most distal seismic unit of the prograding wedge. It pinches out at a rather constant depth of about $140 \mathrm{~m}$; its lower boundary (D70) is an erosional discontinuity that truncates the underlying deposits, and progressively becomes conformable seaward. The internal seismic is similar to that of U147, with continuous alternating high and low amplitude reflections (Fig. 7).

Seismic profiles also show, especially within units U151, U152 and U154, a U-shaped morphology of seismic reflections infilling a depression incised in U147. In U151/U152, the reflections are locally discontinuous, recording the instability of the wedge, whereas U154 displays draping facies (Fig. 8A). When mapped in 3D, these depocentres run along a NE-SW direction, and connect to the South with the Bourcart canyon head and to the North to the fluvial network (3 in Fig. 4) described previously.

Unit U155 is only observable on the top of the sandy prism PII and corresponds to a transgressive reworking of underlying deposits (Bassetti et al., this volume). 


\subsection{Sedimentary facies}

The main lithological and sedimentological characters of 4 piston cores sampled on the Bourcart-Hérault interfluve (Fig. 9), along or very close to a NW-SE Chirp seismic profile shown in Fig. 6, are briefly described here. The ${ }^{14} \mathrm{C}$ dates are summarized in Table 1.

Core MD99-2350 is located at $98 \mathrm{~m}$ water depth. It was retrieved from the sandy facies of prism PII, and is therefore only $2.57 \mathrm{~m}$ in length (Fig. 9). However, it allows to sample the discontinuity between the fine to medium (median around 200-250 $\mu \mathrm{m}$ ) bioclastic, well-sorted sands of unit U155 (50 upper $\mathrm{cm}$ in the core) and the alternating sands and silts of the bottomsets of unit U147. The surface bounding the 2 units displays a very coarse lag with shells, pebbles and reworked material (Bassetti et al., this volume). A sample from the top of U147 yields and ages of about $28 \mathrm{cal}$. kyr BP, and another one from the bottom of U155 gives an age of about 12 cal. kyr BP.

Core MD99-2349 is located at $128 \mathrm{~m}$ water depth. It sampled units U147, U151, and U152. U147 consists of clayed silt (mean grain size of $30 \mu \mathrm{m}$ ), though only $50 \mathrm{~cm}$ of this unit were recovered; the unit is dated at about 41 cal. kyr BP (see Table 1 and Figs 9 and 10) and is overlain by a $3 \mathrm{~m}$ thick interval with coarse shelly sands alternating with silts. The boundary between the two intervals likely corresponds to the seismic discontinuity of D63. The upper $15 \mathrm{~m}$ of the core show alternating millimetric to centimetric silty clay and silt laminae, with intervals where fine to medium sand beds are more abundant. Sandy or silty beds have sharp or even erosional base and display a clear fining upward trend. Bioturbation is abundant within the fine-grained beds, and generally incorporates coarser (silty) material from the overlying beds. This pattern is similar to the storm graded beds described by Aigner (1985). Within the 15-0 m interval, which corresponds to the 28 to 20 cal. kyr BP interval, an overall coarsening upward is observed. Between 7.5 and $8.5 \mathrm{~m}$, sand beds are much more abundant and correlate with discontinuity D65 on seismic profiles. This reflection is dated at about 24 cal. kyr BP.

Core MD99-2348 is located at 296 m water depth. It sampled seismic units U154 and U152 (Fig. 9). The core displays homogeneous bioturbated grey silty clay (median of $10 \mu \mathrm{m}$ at the top of the core, $6 \mu \mathrm{m}$ at the bottom) with abundant organic matter spots and bioturbation. A thin bed of sand is observed at the top of the core, as on most of other cores sampled around the Bourcart canyon head (Gaudin et al., this volume). The seismic discontinuity D70, that 
bounds units U152 and U154, is positioned at about $9 \mathrm{~m}$ on the core, and corresponds to a slight change in the density. Sedimentation rate calculated from ${ }^{14} \mathrm{C}$ dates is very high, especially between 21 and $18 \mathrm{cal}$. kyr BP, where it reaches $2.5 \mathrm{~m} / \mathrm{kyr}$. This allows precise dating of the transition between units U152 and U154 (D70) at about 20 cal. kyr BP. The time span represented by U154 ranges from 20 to 15 cal. kyr BP. Holocene deposits are absent in this core.

Core CLKS-11 is located at $157 \mathrm{~m}$ water depth and is very similar to core MD99-2348 but only sampled U154 (Fig. 9). The only difference is that organic fragments are more abundant, probably because the core is located in a more proximal position with respect to the MD992348. The ${ }^{14} \mathrm{C}$ ages obtained on this core are consistent with those from MD99-2348.

The sedimentary facies, observed on both MD99-2348 and CLKS-11, indicate an offshore environment (Reading and Collinson, 1996) beyond the storm wave base.

\subsection{Paleonvironmental constraints based on fossil content}

\section{a) Temperature}

Within the fine-grained fraction of seismic unit U152, cold species of benthic foraminifera (such as Uvigerina peregrina, Hyalinea baltica, Cassidulinidae spp.), and planktonic foraminifera (Globigerina pachyderma sinistrally coiled, Globigerina glutinata) are observed (Bourdillon, 1994). Seismic units U151 and U152 also contain typical cold boreo-celtic guests in the Mediterranean Pleistocene such as the molluscs Pseudamussium septemradiatum, Chlamys islandica, Arctica islandica, Mya truncata, and Buccinum humphreysianum.

\section{b) Paleobathymetry}

A paleobathymetric reconstruction of core MD99-2349 succession can be proposed. Unit U147 includes mollusc taxa (e.g. the bivalves Bathyarca grenophia, Kelliella miliaris and Venus casina, the gastropod Alvania testae and thecosomatous pteropods), indicative of relatively deep open shelf-upper slope environments (ca. 60-120 m); sandy beds in this same unit contain an assemblage dominated by the serpulid polychaete Ditrupa arietina and the bivalve Corbula gibba, pointing out a sediment-stressed shelf environment whose bathymetry cannot be established with precision, but hypothesised to be in the range of 30-90 m. Unit U151 between 1700-1500 cm contains mollusc taxa of boreo-celtic significance, such as the gastropod Buccinum humphreysianum and the bivalves cf. Modiolus modiolus, Modiolula 
phaseolina (large morphotype), Pseudamussium septemradiatum associated with Aequipecten opercularis, Astarte sulcata, Corbula gibba, Turritella sp. and the bryozoan Turbicellepora coronopus, interpreted as indicative of a muddy-silty mid-outer shelf setting comprised between 40-100 m water depth. In the upper part of this unit the macrofossil assemblages still include boreo-celtic (Buccinum humphreysianum, Arctica islandica, Mya truncata) and other taxa of lesser climatic significance (e.g., Nucula sp., Yoldia sp., Parvicardium minimum, Hiatella arctica etc.). It documents mid-shelf environments with paleodepth likely in the range of 40-60 m; a pelagic input by Thecosomatous pteropods (Spiratella sp.) is a further indication of open marine conditions, while the localised presence of shell layers, serpulid polychaete, minireefs and barnacles (ca. 1450-1460 cm) document times of reduced sediment input. The occurrence of planktonic (e.g., Globigerina pachyderma sinistrally coiled, Globigerina glutinata) and benthic (Hyalinea balthica) foraminifera from units U152 and U147 is a further indication of colder than present (glacial Pleistocene) seawater temperatures at the time of their deposition. Finally the upper part of the succession (U152) has a very faunal content whereas undetermined bivalve fragments are abundant, together with rotaliid and miliolid foraminifera, and plant remains indicative of active prodeltaic environments.

\section{Discussion}

We have collected a set of evidence that demonstrate the effect of relative sea-level changes on strata architecture at the shelf edge during the turnaround of LGM. Thanks to the precise

${ }^{14} \mathrm{C}$ dates obtained from cores and cemented beaches along a dip section that allows to identify time-lines, these evidences can be put together into a stratigraphic framework. The detailed stratigraphy of the Last Glacial Cycle established on the Bourcart-Hérault interfluve (Fig. 7) allows the study of marine accumulation from the shoreface to the upper offshore during the last sea-level lowstand. Taking into consideration both the stratigraphic interpretations and sedimentological information, we evidence rapid fluctuations of the sedimentary environment (Figs 7 and 9). Which factors are the causes of the geometric discontinuities that we observe both on the high resolution seismic and inside the sedimentary record described by the cores? These variations in the sedimentation of a beach or prodelta can be explained either by the fast evolution of the paleobathymetry, either by changes in the conditions of sedimentation (hydrodynamism) or by fluctuations in sediment supply. What is the relative importance of these processes which variably controlled transport and deposition of sediments from 46 to 15 cal. kyr BP? 


\subsection{Evidences for regressive processes at the origin of the high-angle clinoformes in S5}

On Sparker seismic, the steeply dipping sandy clinoforms often downlap onto an erosional seismic discontinuity which affects the underlying low angle clinoforms (Fig. 6); this geometry led some authors to consider the sandy clinoforms as transgressive parasequences (Van Wagoner et al., 1990) formed during the overall deglacial sea-level rise (Tesson et al., 2000). In their interpretation, the erosion surface was a ravinement surface separating regressive prodeltaic muds from transgressive overlying sands. However, in places where accommodation was sufficient, such as the Bourcart canyon head (Fig. 8), continuity exists between high-angle (sandy) clinoforms and gently dipping clinoforms, and therefore demonstrates that deposition of the two facies was synchronous. In locations where accommodation was more restricted (Fig. 6), such as the flat outer continental shelf, a zone of erosion and bypass developed between the sandy clinoforms of the shoreface and the muds deposited beyond the storm wave-base (Berné, 1999). Such surfaces, named regressive surfaces of marine erosion (Plint and Nummendal, 2000), form below sea-level under the erosive action of waves and currents. The major erosional surfaces on the interfluve (D60, D63 and D70), located downstream of the sandy prism, formed prior to LGM and bound units showing a shallowing upward trend. They are consequently regressive surfaces of marine erosion linked to downward shifts of the forced regressive sequence S5, in relation with falls of the wave action base; similar features were described on the Adriatic shelf (Trincardi and Correggiari, 2000; Ridente and Trincardi, 2005). The entire sequence S5 formed during a forced regression, as a seaward and downward shift of the coast line forced by a relative sealevel fall (Posamentier et al., 1992). S5 is topped by transgressive sand bodies and a thin veneer of mobile sands (Bassetti et al., this volume). The dates obtained in this study allow us to confirm a precise time-frame for the deposition of S5 and overlying deposits. Deposition of units U147 through U152 that compose S5 occurred during the overall sea-level fall, between 46 and 20 cal. yr BP (table.1). It should be noted that the deepest evidence of marine erosion detectable on seismic profiles (except around canyon heads where energy is focused) is around $170 \mathrm{~m}$ (Fig. 7), far beyond the lowest sea-level scenario for LGM.

The upper part of U147 is dated both at the bottom of cores MD99-2349 and MD99-2350. The time period for the deposition of this unit is estimated older than $41 \mathrm{cal}$. yr BP at two different positions on the deposit profile. A date of $28.4 \mathrm{cal}$. yr BP is also given at the bottom of U151 within the sandy clinoforms on core MD99-2350 at the erosional surface that corresponds to D63 (analysis performed on complete shell of Mytilus sp., indicative of very 
shallow water environment at the time of deposition). This age post-dates the onset of deposition of U151 and it is consistent with the age of about 25 cal. kyr BP found on core MD99-2349 in the middle part of U151. An age between 20.5 and 20 cal. yr BP is found for D70 based on dates from cores MD99-2348 and CLKS-11. This is also consistent with an age less than 20,517 cal. yr BP from core MD99-2349. In addition, cementation of the beach rocks of "Pierres de Sète" occurred at $21 \pm 0.4$ cal. yr BP, which corresponds to the end of a phase of regression, and therefore to a probable decrease or even stop of sea-level fall.

In summary, the time-frame for the deposition of units U147, U151 and U152 confirms that they formed between MIS-3 and MIS-2, during a period of sea-level fall.

\subsection{Scenario for sedimentation on the Bourcart-Hérault interfluve during the LGM turnaround}

Geological and chronostratigraphic evidence allow us to propose a scenario for the deposition of seismic units and discontinuities that can be observed throughout the study area (from $\mathrm{U} 147$ to U155); this scenario is based on the assumption that the overall subsidence s.l. is in the order of $250 \mathrm{~m} / \mathrm{Myr}$ (Rabineau et al., 2005), equivalent to $5 \mathrm{~m}$ for the last $20 \mathrm{kyr}$. The study area is situated sufficiently far from the former margins of the major ice sheets for sealevel to follow global eustatic changes to a first approximation (Lambeck and Bard, 2000). As to the effect of water loading, a value of about $15 \mathrm{~m}$ is proposed for the Gulf of Lions by the same authors. Our scenario, in any event, refers to relative sea-levels (RSL), as measured with respect to the present mean sea-level. It is summarized in Fig. 11.

\section{a) From $>46$ to 28 cal. kyr BP}

This time interval corresponds to the deposition of the upper part of U147. This unit was sampled at the bottom of cores MD99-2349 and MD99-2350. A paleobathymetry of 80-100 m is indicated by mollusc assemblages at the bottom of core MD99-2349, i.e. at $145 \mathrm{~m}$ below present sea-level; it gives a relative sea-level depth of 45 to $65 \mathrm{~m}$ at around $41 \mathrm{cal}$. kyr BP confirmed by the fine-grained composition of sediments. The basinward migration of the offlap break, together with the erosion of topsets in the upper part of the interfluve, suggests a general fall of relative sea-level during the end of deposition of U147. 
An early connection of a fluvial system of unknown origin (3 in Fig. 4B) with the Bourcart canyon head was established at the end of this period. This incision is oriented along a NESW direction and crosses the interfluve.

Surface D63 corresponds to a major sea-level fall, as evidenced by the abrupt change of sedimentary facies between U147 and U151 in the landward part of the study area (Fig. 8). In the distal part, surface D63 is coeval to the upper most 3 m of U147 on core MD99-2349 (Fig. 10), which correspond to coarse shelly sand, probably reworked and transported seaward from the former shoreline. The best estimate for the time span represented by this surface is 41 to 28 cal. kyr BP.

\section{b) From 28 to 20 cal. kyr BP}

This time interval corresponds to the deposition of U151 and U152 ended by the onset of renewed sea-level fall. This period is interpreted as a phase of stillstand or very slow fall of sea-level for the following reasons:

- the steep clinoforms of the shoreface sands are at a constant depth along a distance of about $7 \mathrm{~km}$ (average shoreline progradation of about $0.9 \mathrm{~m} / \mathrm{yr}$; Fig. 8);

- the transition from aggradation to progradation of the time-equivalent muddy lowangle clinoforms would result from a progressive decrease of accommodation space (the sediment is progressively bypassed beyond the storm wave-base, when available space is occupied by newly deposited sediment);

- paleobathymetry estimates from macrofauna assemblages within core MD99-2349 indicate a depth of about $50 \mathrm{~m}$ in the middle of unit U151 at about $15 \mathrm{~m}$ below seafloor. In unit U152, benthic foraminifera assemblages indicate a depth of about $40 \mathrm{~m}$ (see section $4.4 \mathrm{~b}$ for the details);

- the storm beds observed on core MD99-2349 (Fig. 9) are typically attributed to water depths of 30-40 m (Guillocheau and Hoffer, 1988);

- the overall increase in sand fraction (well illustrated by the upward increase in density and sonic velocity along core MD99-2349; Fig. 10) probably results from progressive infill of available space. Around 20.5 cal. yr BP, however, the abrupt increase in sand faction is likely related to the onset of sea-level fall;

- cementation of beach rocks (90 m water depth or less if some of the cemented material was eroded) at about 21 cal. kyr BP also requires a fairly stable sea-level. This event would pre-date an episode of renewed sea-level fall. 
In the Bourcart canyon head, the end of the 28-20 cal. kyr BP interval is marked by a shift of fluvial connection, from a stream labelled "3" in Fig. 4 to another, labelled "2" and situated further West. The brackish influence observed on the cement of the "Pierres de Sète" beach rocks could result from this fluvial influence.

\section{c) From 20 to 15 cal. kyr BP}

This period corresponds to the deposition of seismic unit U154 and to the period of turnaround of relative sea-level. However, the sediments that could have been deposited between 110 and $140 \mathrm{~m}$ during this period were bypassed or eroded, because they were situated above the lowest sea-level, or above the storm wave-base. As a result, only the finegrained distal component of the LGM shoreface was preserved, below $140 \mathrm{~m}$ water depth. The position of the lowest sea-level is difficult to determine precisely, because the topsets of the sandy clinoforms were generally eroded during the ensuing sea-level rise. Consequently, the scarp that occurs at 110-115 m does not represent the position of the lowest sea-level, but the top of a terrace riser that formed during an ensuing stillstand, as described for instance in lake deposits by Adams and Wesnousky (1998). In any event, it implies that sea-level fell at least down to $110-115 \mathrm{~m}$, and possibly as deep as $140 \mathrm{~m}$ rsl Taking into account a subsidence of $5 \mathrm{~m}$ and water loading effect of $15 \mathrm{~m}$, the estimation of the corresponding global lowest sea-level would be between 95 and 120 m.The high sedimentation rate between 20 and $18 \mathrm{cal}$. kyr BP (2.5 m/kyr) can be explained by the vicinity, at that time, of a probable Rhône related shelf-edge delta (1 in Fig. 4), leading to sediment plumes being swept toward the interfluve by the general anti-clockwise circulation.

The timing of the onset of sea-level rise can be estimated from the abrupt decrease in the sedimentation rate, which occurred between 18 and 17 cal. kyr BP. The scarp observed at 98$105 \mathrm{~m}$ would represent a decrease in the sea-level rise, which occurred before $15.9 \mathrm{cal}$. kyr BP (age of the ravinement surface at $99 \mathrm{~m}$ water depth, Bassetti et al., this volume). The progradation of the glacial shoreface (prism PII) which show seaward an upward trend of progressive downlap, is ended by this paleobathymetric step.

The erosion of the "Pierres de Sète" (carving of up to $20 \mathrm{~m}$ of sand) took place between 21 and $15 \mathrm{cal}$. kyr BP, and this age marks the onset of deposition of thin transgressive sand bodies on the outer shelf (U155). 
In summary, this scenario requires some variations in the rate of relative sea-level changes, with a drastic drop before $28 \mathrm{cal}$. kyr BP, a slow-down during the sea-level fall at about $90 \mathrm{~m}$ rsl at about 21 cal. kyr BP, a minimum sea-level at least at 110-115 m rsl; the onset of sealevel rise between 18 and 17 cal. kyr BP, and a slow down of sea-level rise at a level of about 98-105 m rsl between 17 and 15.9 cal. kyr BP.

\subsection{Heinrich events and seismic reflections}

The imprint of Heinrich events was shown in the Alboran Sea (Cacho et al., 2000) and attributed to the intensification of Deep Western Mediterranean Water formation during periods of cooling, in relation with southward displacement of the Polar Front. In the Gulf of Lions, a very distinct cool interval corresponding to Heinrich event 2 (H2) has been evidenced by multi-proxy analysis of core MD99-2348 (Flores et al., 2005). This interval corresponds to an increase in sand fraction along core MD99-2349, between $7.5 \mathrm{~m}$ and $8.5 \mathrm{~m}$, dated about at 24 cal. kyr BP; it also corresponds to a seismic reflection (D65) that can be tracked seaward up to the bottom of core MD99-2348. Along this core, there is no clear change in lithology but $\mathrm{H} 2$ is marked between 19 and $22.5 \mathrm{~m}$ below sea-floor by a peak in abundance of the foraminifer Neogloboquadrina pachyderma (sinistrally coiled), and in the coccolithophere Emiliana huxleyi $>4 \mu \mathrm{m}$ (a cold water morphotype) (Flores et al., 2005).

A similar pattern is observed at the top of this core between 1 and $3.5 \mathrm{~m}$, which corresponds to an age between 16.5 and 18 cal. kyr BP (Flores et al., 2005; Berné et al., 2004). This age matches well with the age of H1 of Bond et al. (1992). Nevertheless, the erosion of unit U152 during relative sea-level rise did not allow preservation of H1 in core MD99-2349.

The process leading to increased sand content must be linked to enhancement of northwesterly winds (Mistral and Tramontane), which control the formation of dense cold water. In the present-day highstand situation, it has been shown that periods of increased northwesterly wind during winter triggers cascading currents (Palanques et al., this volume); these currents transport sand downslope, as shown by the presence of recent ( $<100 \mathrm{yr}$ ) sand beds buried in muds within the Bourcart canyon head (Gaudin et al., this volume).

In conclusion, even if there are no IRD (Ice Rafted Debris) in the Gulf of Lions, we can identify a seismic reflection associated to Heinrich event 2, as there are reflections related to IRD in NE Atlantic (Auffret et al., 1998). 


\section{Conclusion}

The new VHR seismic and lithologic data set from the Bourcart-Herault interfluve provide a high-resolution marine sedimentary record of the Last Glacial Maximum at the shelf edge of the Gulf of Lions. Within the last sedimentary sequence S5, which corresponds to the last glacial 100 kyr-cycle, several units display a good record of sea-level changes that occurred between 46 and 15 cal kyr BP. This particular interval is only recorded in the critical area constituted by the shelf break (above the major slump scars that cut across the continental slope at about $500 \mathrm{~m}$ water depth and deeper). Through time, three zones of connection of fluvial systems with the shelf break can be identified, including a possible distributary of the Rhône.

Because of the high detrital input, sedimentation rate reached a maximum of $2.5 \mathrm{~m} / \mathrm{kyr}$ between 21-18 kyr. Sediment supply stopped abruptly at $15 \mathrm{kyr}$, because of the rapid landward shift of fluvial outlets during the deglacial sea-level rise. Geomorphological, sedimentological and paleoenvironmental information indicate that the fluctuation of sea-level around LGM was punctuated by periods of slowing down and acceleration. Three periods of stillstand are identified and dated at 90 m relative sea-level (21 cal. kyr BP), 110-115 m rsl (18-17 cal. kyr BP), and 98-105 m rsl (before 15.9 cal. kyr BP). The position of relative sealevel during the maximum lowstand is not known, but is at least $115 \mathrm{~m}$. During this time, periods of increased northwesterly winds favoured transport of coarser sediment at the shelf edge, in relation with cascading deep water. This process creates a distinct sandy interval during the period of Heinrich event 2, at the origin of amplitude anomaly on very high resolution seismic data.

\section{Acknowledgements}

This research is supported by the European Community through the EUROSTRATAFORM (contract EVK3-2002-00079) and PROMESS 1 (contract EVR1-CT-2002-40024) projects. Initial support was provided by "Region Languedoc-Roussillon”, Ifremer and the French "Margins” program. Additional support was provided by the French Agence Nationale de la Recherche (ANR, contract NT05-3-42040). Captains and crews of "Marion Dufresne”, "Le Suroît” and “L'Europe” are thanked for assistance during cruises "Images 5”, “Basar” 1 and 2, "Strataform”. A special thank is due to Nicolas Thouveny and Yvon Balut, (respectively chief scientist and operational manager) for their dedication during cruise Images 5 . The technical staffs of Genavir (data acquisition) and Ifremer/GM (data processing) are warmly 
thanked (A.S. Alix, R. Apprioual, F. Dubois, F. Duval, G. Floch, I. Jégou, E. Le Drezen, E. Leroux, B. Loubrieu, A. Normand, D. Pierre, C. Satra). J. Baztan and M. Gaudin are thanked for lively discussions on the origin and evolution of canyons. Contribution $n^{\circ} 985$ of the IUEM, European Institute for Marine Studies (Brest, France) and $n^{\circ} 1503$ of the ISMARCNR.

Finally, we would like to thank the reviewers, Dr G-J Weltje, Dr D. Ridente and Editor Dr F. Trincardi, for their thoughtful suggestions to improve the manuscript.

\section{References}

Adams, K.D. and Wesnousky, S.G., 1998. Shoreline processes and the age of the Lake Lahontan Highstand in the Jessup embayment, Nevada. Geological Society of America Bulletin, 110: 1318-1332.

Aigner, T., 1985. Storm depositional systems. Lecture Notes in Earth Sciences, 3. Springer Verlag, Berlin, 174 pp.

Almagor, G., 1979.Relict sandstones of Pleistocene age on the continental shelf of Northern Sinai and Israel. Israel Journal of Earth-Sciences, 28: 70-76.

Aloïsi, J.C., 1986. Sur un modèle de sédimentation deltaïque: contribution à la connaissance des marges passives. Thèse de doctorat d'Etat Thesis, Université de Perpignan, Perpignan, $162 \mathrm{pp}$.

Aloïsi, J.C., Auffret, G.A., Auffret, J.P., Barusseau, J.P., Hommeril, P., Larsonneur, C. and Monaco, A., 1977. Essai de modélisation de la sédimentation actuelle sur les plateaux continentaux français. Bull. Soc. géol. France, 19(2): 183-195.

Auffret, G., Dennielou, B., Boelaert, A., Bassinot, F., Labeyrie, L., Pujol, C. and Loncaric, N., 1998. Physical properties and environmental implications of thick Heinrich layers from the Meriadzek Terrace (Bay of Biscay, NE Atlantic Ocean), 6th International Conference on Paleoceanography, Lisbon.

Bard, E., Arnold, M., Hamelin, B., Tisnerat-Laborde, N. and Cabioch, G., 1998. Radiocarbon calibration by means of mass spectrometric 230Th/234U and 14C ages of corals. An updated data base including samples from Barbados, Mururoa and Tahiti. Radiocarbon, 40(3): 1085-1092.

Bard, E., Hamelin, B., Arnold, M., Montaggioni, L., Cabioch, G., Faure, G. and Rougerie, F., 1996. Deglacial sea-level record from Tahiti corals and the timing of global meltwater discharge. Nature, 382: 241-244.

Bard, E., Hamelin, B. and Fairbanks, R.G., 1990. U-Th ages obtained by mass spectrometry in corals from Barbados: sea level during the past 130,000 years. Nature, 346: 456458.

Bartov, Y., Stein, M., Enzel, Y., Agnon, A. and Reches, Z., 2002. Lake Levels and Sequence Stratigraphy of Lake Lisan, the Late Pleistocene Precursor of the Dead Sea. Quaternary Research, 57(1): 9-21.

Bassetti, M.A., Jouët, G., Dufois, F., Berné, S., Rabineau, M., Taviani, M. Sand bodies at the shelf edge in the Gulf of Lions (Western Mediterranean): deglacial history and modern processes. Marine Geology, this volume. 
Bassinot, F., Labeyrie, L., Vincent, E., Quidelleur, X., Shackleton, N.J. and Lancelot, Y., 1994. The astronomical theory of climate and the age of the Brunhes-Matuyama magnetic reversal. Earth Planet. Sci. Lett., 126: 91-108.

Baztan, J., Berné, S., Olivet, J.L., Rabineau, M., Aslanian, D., Gaudin, M., Réhault, J.P. and Canals, M., 2005. Axial incision: The key to understand submarine canyon evolution (in the western Gulf of Lions). Marine and Petroleum Geology, 22 (6-7): 805-826.

Baztan, J., 2004. Formation et évolution des canyons sous-marins du Golfe du Lion : relation avec les cycles glacio-eustatiques. Thèse de Doctorat, UBO- IFREMER, 450 pp.

Bentounsi, F., 1990. ECORS - Golfe du Lion. Interprétation des profils de sismique réflexion longue écoute - cinématique d'ouverture de la Méditerranée Occidentale. Mémoire de D.E.A, Université de Bretagne Occidentale, Brest, 69 pp.

Berné, S. and Gorini, C., 2005. The Gulf of Lions: an overview of recent studies within the French "Margins" Programme. Marine and Petroleum Geology, 22 (6-7): 691-693.

Berné, S., Rabineau, M., Flores, J.A. and Sierro, F.J., 2004. The impact of quaternary global changes on strata formation: exlporation of the shelf edge in the Northwest Mediterranean Sea. Oceanography, 17(4): 92-103.

Berné, S., Aloïsi, J.C., Baztan, J., Dennielou, B., Droz, L., Dos Reis, T., Lofi, J., Méar, Y. and Rabineau, M., 2002. Notice de la carte morpho-bathymétrique du Golfe du Lion. IFREMER et Région Languedoc Roussillon, Brest, 48 pp.

Berné, S., Loubrieu, B. and the CALMAR shipboard party, 1999. Canyons and recent sedimentary processes on the western Gulf of Lions margin. First results of the Calmar cruise. Comptes Rendus de l'Académie des Sciences de Paris, 328: 471477.

Berné, S., 1999. Dynamique, architecture et préservation des corps sableux de plateforme. Mémoire d'habilitation à diriger des recherches, Université de Lille 1, Lille, 111 pp.

Berné, S., Lericolais, G., Marsset, T., Bourillet, J.F. and de Batist, M., 1998. Erosional shelf sand ridges and lowstand shorefaces: examples from tide and wave dominated environments of France. Journal of Sedimentary Research, 68(4): 540-555.

Bernier, P., 2000. Les Pierres de Sète: un indicateur paléobathymétrique et paléoenvironnemental, Atelier Golfe du Lion du GDR Marges, Paris.

Biju-Duval, B., 1984. Les marges continentales françaises de la Méditerranée. In: G. Boillot (Editor), Les marges actuelles et fossiles autour de la France. Masson, Paris, pp. 249-334.

Bond, G., Broecker, W., Johnsen, S., McManus, J., Labeyrie, L., Jouzel, J. and Bonani, G., 1993. Correlations between climate records from North Atlantic sediments and Greenland ice. Nature, 365: 143-147.

Bond, G., Heinrich, H., Broecker, W., Labeyrie, L., McManus, J., Andrews, J., Huon, S., Jantschik, R., Clasen, S., Simet, C., Tedesco, K., Klas, M., Bonani, G. and Ivy, S., 1992. Evidence for massive discharges of icebergs into the North Atlantic Ocean during the last glacial period. Nature, 360: 245-249.

Bossuet, G., Ruffaldi, P., Magny, M., Richard, H. and Mouthon, J., 1996. Dynamique et approche quantitative des remplissages fini- et postwürmiens du bassin lacustre de Cerin (Jura, France). Bulletin de la Société Géologique de France, 167(4): 483494.

Bourdillon, C., 1994. Micropaléontologie de sédiments de sondage dans le Golfe du Lion (Mer Méditerranée). BRGM internal report N1864, Orléans, 15 pp. 
Cacho, I., Grimalt, J.O., Sierro, F.J., Shackleton, N. and Canals, M., 2000. Evidence for enhanced Mediterranean thermohaline circulation during rapid climatic coolings. Earth and Planetary Science Letters, 183: 417-429.

Cacho, I., Grimalt, J.O., Pelejero, C., Canals, M., Sierro, F.J., Flores, J.A. and Shackleton, N., 1999. Dansgaard-Oeschger and Heinrich event imprints in Alboran Sea paleotemperatures. Paleoceanography, 14(6): 698-705.

Cattaneo, A., Correggiari, A., Marsset, T., Thomas, Y., Marsset, B. and Trincardi, F., 2004. Seafloor undulation pattern on the Adriatic shelf and comparison to deep-water sediment waves. Marine Geology, 213(1-4): 121-148.

Chappell, J. and Polach, H., 1991. Post-glacial sea-level rise from a coral record at Huon Peninsula, Papua New Guinea. Nature, 349(10): 147-149.

Clark, P.U. and Mix, A.C., 2002. Ice sheets and sea level of the Last Glacial Maximum. Quaternary Science Reviews, 21: 1-7

Clauzon, G., 1974. L'hypothèse eustatique et le creusement pré-pliocène de la vallée du Rhône. Annales de Géographie, 456: 129-140.

Dansgaard, W., Johnsen, S.J., Clausen, H.B., Dahl-Jensen, D., Gundestrup, N.S., Hammer, C.U., Hvidberg, C.S., Steffensen, J.P., Sveinbjörnsdottir, A.E., Jouzel, J. and Bond, G., 1993. Evidence for general instability of past climate from a 250-kyr ice-record. Nature, 364: 218-220.

Droz, L. and Bellaiche, G., 1985. Rhône deep-sea fan: morphostructure and growth pattern. American Association of Petroleum Geologists Bulletin, 69: 460-479.

Durrieu de Madron, X., 1992. Hydrography and nepheloid structures in the Grand-Rhône canyon. Continental Shelf Research: 457-477.

Ehlers, J., 1996. Quaternary and glacial geology. Wiley, New York and Toronto, 578 pp.

Fairbanks, R.G., 1989. A 17,000-year glacio-eustatic sea level record: influence of glacial melting rates on the Younger Dryas event and deep-ocean circulation. Nature, 342: 637-642.

Flores, J.A., Sierro, F.J., Pérez-Folgado, M., Colmenero-Hidalgo, E., Gravalosa, J.M., Bárcena, M.A., Grimalt, J., Berné, S., Dennielou, B., Curtis, J.H. and Hodell, D.A., 2005. Abrupt climatic changes during the last climatic cycles in the Gulf of Lions (Western Mediterranean) revealed by micropaleontological and geochemical tools, European Geosciences Union (EGU). Geophysical Research Abstracts, Vienna, pp. 02208.

Gaudin, M., Berné, S., Jouanneau, J-M., Palanques, A., Puig, P., Mulder, T., Cirac, P., Rabineau, M., Imbert, P. Massive sand beds attributed to deposition by dense water cascades in the Bourcart canyon head, Gulf of Lions (northwestern Mediteranean Sea). Marine Geology, this volume.

Gensous, B. and Tesson, M., 1996. Sequence stratigraphy, seismic profiles, and cores of Pleistocene deposits on the Rhône continental shelf. Sedimentary Geology, 105: 183-190.

Gensous, B., Williamson, D. and Tesson, M., 1993. Late-Quaternary transgressive and highstand deposits of a deltaic shelf (Rhône delta, France). In: H.W. Posamentier, C.P. Summerhayes, B.A. Haq and G.P. Allen (Editors), Sequence stratigraphy and facies associations. International Association of Sedimentologists Special Publication 18, Blackwell, Oxford, pp. 197-212.

Gorini, C., Le Marrec, A. and Mauffret, A., 1993. Contribution to the structural and sedimentary history of the Gulf of Lions (Western Mediterranean) from the ECORS profiles, industrial seismic profiles and well data. Bulletin de la Société Géologique de France, 164(3): 353-363. 
Gueguen, E., 1995. La Méditerranée Occidentale: un véritable océan. Exemple de segmentation des marges et de hiatus cinématiques. Implications sur les processus d'amincissement crustal. Thèse de Doctorat, Université de Bretagne Occidentale, Brest, $281 \mathrm{pp}$.

Guillocheau, F. and Hoffer, M., 1988. Zonation des dépôts de tempètes en milieu de plateforme: le modèle des plateformes nord-gondwanienne et armoricaine à l'Ordovicien et au Dévonien. Comptes Rendus de l'Académie des Sciences de Paris, 307: 1909-1916.

Heinrich, H., 1988. Origin and consequences of cyclic ice rafting in the Northeast Atlantic Ocean during the past 130,000 years. Quaternary Research, 29: 142-152.

Hsü, K.J., Cita, M.B. and Ryan, W.B.F., 1973. The origine of the Mediterranean evaporites, Initial reports of the deep sea drilling project. D.C., U.S. Government Printing Office, Washington, pp. 1203-1231.

Imbrie, J., Hays, J.D., Martinson, D.G., McIntyre, A., Mix, A.C., Morley, J.J., Pisias, N.G., Prell, W.L. and Shackleton, N.J., 1984. The orbital theory of pleistocene climate: support from a revised chronology of the marine $\mathrm{d} \mathrm{O}^{18}$ record. In: A. Berger, Imbrie, J., Hays, J., Kukla, G., Saltzman, B. (Editor), Milankovitch and climate. Series C: Mathematical and Physical Sciences.

Labeyrie, L.D., 1989. Une courbe du niveau marin sur 150000 ans. d'après Labeyrie, 1987, pers. com.

Labeyrie, L.D., 1987. Variations in mode of formation and temperature of oceanic deep waters over the past 125,000 years. Nature, 327(6122): 477-482.

Lambeck, K. and Bard, E., 2000. Sea-level changes along the French Mediterranean coast for the past 30000 years. Earth and Planetary Science Letters, 175: 203-222.

Lee, H.J., Syvitski, J.P.M., Parker, G., Orange, D., Locat, J., Hutton, E.W.H. and Imran, J., 2002. Distinguishing sediment waves from slope failure deposits: field examples, including the 'Humboldt slide', and modelling results. Marine Geology, 192(1-3): 79-104.

Lericolais, G., Allenou, J.P., Berné, S. and Morvan, P., 1990. A new system for acquisition and processing of very high-resolution seismic reflection data. Geophysics, 55(8): 1036-1046.

Lofi, J., Rabineau, M., Gorini, C., Berné, S., Clauzon, G., De Clarens, P., Tadeu Dos Reis, A., Mountain, G.S., Ryan, W.B.F., Steckler, M.S. and Fouchet, C., 2003. PlioQuaternary prograding clinoform wedges of the western Gulf of Lion continental margin (NW Mediterranean) after the Messinian Salinity Crisis. Marine Geology, 198(3-4): 289-317.

Locker, S.D., Hine, A.C., Tedesco, L.P. and Shinn, E.A., 1996. Magnitude and timing of episodic sea-level rise during the last deglaciation. Geology, 24 (9): 827-830.

Martinson, D.G., Pisias, N.G., Hays, J.D., Imbrie, J., Moore, T.C., Jr. and Shackleton, N.J., 1987. Age dating and the orbital theory of the ice ages: development of a highresolution 0 to 300,000-year chronostratigraphy. Quaternary Research, 27: 1-29.

Migeon, S., Savoye, B., Zanella, E., Mulder, T., Faugères, J.C. and Weber, O., 2001. Detailed seismic-reflection and sedimentary study of turbidite sediment waves on the Var Sedimentary Ridge (SE France): significance for sediment transport and deposition and for the mechanisms of sediment-wave construction. Marine and Petroleum Geology, 18: 179-208.

Millot, C., 1999. Circulation in the Western Mediterranean Sea. Journal of Marine System, 20: 423-442.

Millot, C., 1990. The Gulf of Lions' hydrodynamics. Continental Shelf Research, 10(9-11): 885-894. 
Mitchum, R.M., Vail, P.R. and Sangree, J.B., 1977. Seismic stratigraphy and global changes of sea level, part 6: Stratigraphic Interpretation of Seismic Reflection Patterns in Depositional Sequences. In: C.E. Payton (Editor), Seismic stratigraphy Application to hydrocarbon exploration. AAPG Mem. 26, Tulsa, Oklahoma, pp. 117-133.

Myers, P.G., Haines, K. and Rohling, E.J., 1999. Modelling the paleo-circulation of the Mediterranean: the Last Glacial Maximum and the Holocene with emphasis on the formation of Sapropel. Paleoceanography.

Palanques, A., Durrieu de Madron, X., Puig, P., Fabres, J., Guillén, J., Calafat, A., Canals, M., Bonnin, J. Suspended sediment fluxes and transport processes in the Gulf of Lions submarine canyons. The role of storms and dense water cascading. Marine Geology, this volume.

Plint, A.G. and Nummendal, D., 2000. The falling stage systems tract: recognition and importance in sequence stratigraphy. In: D. Hunt and R.L. Gawthorpe (Editors), Sedimentary responses to forced regressions. Geological Society, London, pp. 117.

Posamentier, H.W., Allen, G.P., James, D.P. and Tesson, M., 1992. Forced regressions in a sequence stratigraphic framework: concepts, examples and exploration significance. American Association of Petroleum Geologists Bulletin, 76: 16871709.

Rabineau, M., Berné, S., Aslanian, D., Olivet, J.L., Joseph, P., Guillocheau, F., Bourillet, J.F., Le Drezen, E. and Grangeaon, D., 2005. Sedimentary sequences in the Gulf of Lion: a record of 100,000 years climatic cycles. Marine and Petroleum Geology, 22 (6-7): 775-804.

Rabineau M., 2001. Un modèle géométrique et stratigraphique des séquences de dépôts quaternaires de la plate-forme du Golfe du Lion : enregistrement des cycles glacioeustatiques de 100000 ans. Thèse de Doctorat, Université de Rennes 1 and IFREMER, $392+70$ pp. (2 vols).

Reading, H.G. and Collinson, J.D., 1996. Clastic coasts. In: H.G. Reading (Editor), Sedimentary environments; processes, facies and stratigraphy. Blackwell Scientific Publications, Oxford, pp. 688.

Ridente, D. and Trincardi, F., 2005. Pleistocene "muddy" forced-regression deposits on the Adriatic shelf: A comparison with prodelta deposits of the late Holocene highstand mud wedge. Marine Geology, 222-223: 213-233.

Rohling, E.J., Fenton, M., Jorissen, F.J., Bertrand, P., Ganssen, G. and Caulet, J.P., 1998. Magnitudes of sea level lowstands of past 500,000 years. Nature, 394: 162-165.

Ruddiman, W.F., McIntyre, A. and Raymo, M., 1986. Paleoenvironmental results from North Atlantic sites 607 and 609. In: S. Orlofsky (Editor), Initial Reports of the Deep Sea Drilling Project, Washington, pp. 855-878.

Ruddiman, W.F., 1977. North Atlantic ice-rafting: a major change 75000 years before present. Science, 196: 1208-1211.

Schock, S.G., Leblanc, L.R. and Mayer, L.A., 1989. Chirp subbottom profiler for quantitative sediment analysis. Geophysics, 54: 445-450.

Shackleton, N.J., 2000. The 100,000-year Ice-Age cycle found to lag temperature, carbon dioxide, and orbital eccentricity. Science, 289: 1897-1902.

Shackleton, N.J., 1987. Oxygen isotopes, ice volume and sea-level. Quaternary Science Reviews, 6: 183-190.

Shackleton, N.J., 1977. The oxygen isotope stratigraphic record of the Late Pleistocene. Philosophical Transactions of the Royal Society of London B, 280: 169-182. 
Siddall, M., Rholing, E.J., Almogi-Labin, A., Hemleben, C., Meischner, D., Schmelzer, I. and Smeed, D.A., 2003. Sea-level fluctuations during the last glacial cycle. Nature, 423: 853-858.

Sioni, S., 1997. Mer Ionienne et Apulie depuis l'ouverture de l'Océan Alpin. Thèse de Doctorat, Université de Bretagne Occidentale, Brest.

Skene, K.I., Piper, D.J.W., Aksu, A.E. and Syvitski, J.P.M., 1998. Evaluation of the global oxygen isotope curve as a proxy for Quaternary sea level by modeling of delta progradation. Journal of Sedimentary Research, 68(6): 1077-1092.

Stuiver, M., Reimer, P.J., Bard, E., Beck, J.W., Burr, G.S., Hughen, K.A., Kromer, B., McCormac, F.G., Van Der Plicht, J. and Spurk, M., 1998. INTCAL98 Radiocarbon age calibration 24,000 - 0 cal BP. Radiocarbon, 40: 1041-1083.

Tesson, M., Posamentier, H. and Gensous, B., 2000. Stratigraphic organisation of Late Pleistocene deposits of the western part of the Rhone shelf (Languedoc shelf) from high resolution seismic and core data. A.A.P.G. Bull., 84(1): 119-150.

Tesson, M., Gensous, B. and Ravenne, C., 1994. Architecture of Pleistocene deposits of the Languedoc shelf (Gulf of Lions, France). Relations with glacio-eustatic cycles and stratigraphic implications, 15th IAS Regional Meeting, Ischia, pp. 401-403.

Tesson, M., Allen, G.P. and Ravenne, C., 1993. Late Pleistocene shelf-perched lowstand wedges on the Rhône continental shelf. In: H.W. Posamentier, C.P. Summerhayes, B.A. Haq and G.P. Allen (Editors), Sequence stratigraphy and facies associations. IAS Spec. Pub. 18, Blackwell Sci. Pub., Oxford, pp. 183-196.

Trincardi, F. and Correggiari, A., 2000. Quaternary forced regression deposits in the Adriatic Basin and the record of composite sea-level cycles. In: D. Hunt and R.L. Gawthorpe (Editors), Sedimentary responses to forced regressions. Geological Society, London, pp. 245-269.

Thunell, R., Rio, D., Sprovieri, R. and Vergnaud-Grazzini, C., 1991. An overviewof the postMessinian paleoenvironmental history of the Mediterranean. Paleoceanography, 6(1): 143-164.

Van Wagoner, J.C., Mitchum, R.M., Campion, K.M. and Rahmanian, V.D., 1990. Siliciclastic sequence stratigraphy in well logs, cores and outcrops: Concepts for high resolution correlation of time and facies. American Association of Petroleum Geologists, Methods in Exploration Series No 7, 55 pp.

Waelbroeck, C., Labeyrie, L.D., Michel, E., Duplessy, J.-C., McManus, J., Lambeck, K., Balbon, E. and Labracherie, M., 2002. Sea level and deep water changes derived from benthic foraminifera isotopic record. Quaternary Science Review, 21(1-3): 295-305. 


\section{Figure captions}

Fig. 1: Geographic and hydrographic settings of the Gulf of Lions. The present day morphology and the sand distribution on the continental shelf (Aloisi, 1986) illustrate the effect of the last deglacial sea-level rise with (1) Pleistocene prodeltaic/lower shoreface muds beyond about $120 \mathrm{~m}$ water depth, (2) Pleistocene shoreface sands between about $80 \mathrm{~m}$ and 120 m water depth, (3) a deglacial littoral prism with prodeltaic muds (between about 20 and $80 \mathrm{~m}$ water depth) and shoreface sands (between the coastline and about $20 \mathrm{~m}$ water depth). The general circulation is mainly driven by the anti-clockwise flow of the Liguro-Provençal or Northern Current (Millot, 1990).

Seismic profiles and sediment cores are localised on the Bourcart-Hérault interfluve. BC: Bourcart Canyon; HC: Hérault Canyon.

Fig. 2: Stratigraphic interpretation from high-resolution Sparker seismic lines P-1110 (position in Fig. 1). A) The NW-SE transect across the platform illustrates the stacking of the last 5 sedimentary sequences (S1 to S5) bounded by major discontinuities (D30 to D70). Vwater $=1500 \mathrm{~m} . \mathrm{s}^{-1}$ and Vsed $=1600 \mathrm{~m} . \mathrm{s}^{-1}$ are used for depth conversions. B) Recognition of the sedimentary motif (modified from Rabineau et al., 2005). Deposits are organized with a horizontal motif consisting of: (1) PI prisms with gently dipping clinoforms $\left(<1^{\circ}\right)$ and (2) PII prisms with relatively high-angle clinoforms (from 3 to $7^{\circ}$ ). Thin black lines are time-lines. PI corresponds to the seaward termination of PII, beyond the action of waves, and could be partly preserved during a general sea-level fall, whereas PII is seaward transferred due to the regressive erosion. $\mathbf{C}$ ) Correlation between the sedimentary sequences on the shelf and the last 5 glacial/interglacial 100 kyr-glacio-eustatic cycles (Rabineau et al., 2005). Each major erosional surface (D30 to D70) corresponds to a relative low sea-level of the Specmap eustatic curve (Imbrie et al., 1984).

Fig. 3: Global sea-level changes according to different authors A) for the last $120 \mathrm{kyr}$, and B) for the 35-10 kyr period, based on isotopic studies, coral reef studies, or interpretation of paleodelta fronts (Rohling et al., 1998; Siddall et al., 2003; Waelbroeck et al., 2002; Bassinot et al., 1994; Labeyrie, 1987 and 1989; Bard et al., 1990; Fairbanks, 1989; Skene et al., 1998; Shackleton, 2000; Imbrie et al., 1984). The right axis represents the mean ocean sea-level derived by Shackleton (2000) from atmospheric $\delta^{18}$ O. Note the differences between various curves in the order of $40 \mathrm{~m}$ during Marine Isotope Stage 3 and 2. 
Fig. 4: A) Swath bathymetric map of the Bourcart-Hérault interfluve, based on EM1000 and EM 300 swath bathymetric data. The study area is comprised between 90 and $350 \mathrm{~m}$ water depth, in the vicinity of the Bourcart (Aude) and Hérault canyons. Sparker and mud penetrator (Chirp) seismic data include a NW-SE transect along the canyon interfluve sampled by sediment cores. B) Morphological interpretation. The Hérault canyon was connected during LGM to the Rhône (1). Similarly, another stream (Aude, Agly or Hérault), flowing from the West (2), reached the western flank of the Bourcart canyon. Seismic data also indicate that a stream (3) flowed to the interfluve, and fed an eastern branch of the Bourcart canyon head. Besides the shelf break, major scarp are observed at a water depth of 98-105 m and 110$115 \mathrm{~m}$.

Fig. 5: A) Close-up view of the "Pierres de Sète" zone. This elongated relief (7 km lateral extent and $300 \mathrm{~m}$ width) is parallel to bathymetric contour lines, and culminates at $90 \pm 0.5 \mathrm{~m}$ water depth (20 m above the surrounding sea-floor). B) Seismic profile P-1005 and C) its interpretation show that cemented sands top the clinoforms of the upper shoreface sand facies, and that erosion occurred, especially at the bottom of the landward flank of the relief. A sample was dredged at the top of this ridge (CLDR01) and shows that it is made of coarse silicoclastic sands cemented during early diagenetic processes with an age of cementation of $17,785 \pm 240{ }^{14} \mathrm{C}$ yr BP (21 cal. yr BP).

Fig. 6: A) High-resolution seismic Sparker line P-7020 (position in Fig. 4) along the canyon interfluve (dip section). Vwater $=1500 \mathrm{~m} \cdot \mathrm{s}^{-1}$ and Vsed $=1600 \mathrm{~m} \cdot \mathrm{s}^{-1}$ are used for the depth conversions. B) Stratigraphic interpretation and close-up views. The five major seismic sequences (S1 to S5) attributed to $100 \mathrm{kyr}$-cycles are identified. In each major sequence, the high-angle sandy clinoforms often downlap an erosional seismic discontinuity, which affects the underlying low angle clinoforms. A wavy facies, similar to undulations observed on several continental shelves and slopes, is observed within S5 and within other, older sequences, such as sequence S4.

Fig. 7: Very high-resolution seismic Chirp profile P-7020ch (A) (position in Fig. 4) and interpretation (B). The profile is positioned at the same location as Sparker profile of Fig. 6. Steps and terraces identified on bathymetric maps are positioned. Within the last glacial cycle sequence (S5), several units (U147, U151, U152, U154 and U155) can be identified 
throughout the study area. The close-up view shows the position of core MD992349 within the wavy facies.

Fig. 8: High-resolution seismic Sparker lines P-7056-7049 (A) and interpretation (B) (position in Fig. 4) across the cemented sands and the easterly Bourcart canyon head. Steps and terraces identified on bathymetric maps are positioned. Note the continuity between highangle clinoforms of the sandy facies (PII) and low-angle clinoforms of the offshore muds (PI), demonstrating that these deposits formed as forced regressions (see explanation in text). Within U151, U152 and U154, the U-shape of seismic reflections records the infill of a depression incised within U147. This infill runs along a NW-SE direction and connects to the South with the Bourcart canyon head, and to the North to the fluvial drainage network (3 in Fig. 4).

Fig. 9: Correlation between core and seismic data along the Bourcart-Hérault interfluve. Correlations between cores MD99-2350, MD99-2349, CLKS-11 and MD99-2348 are based on seismic reflections and ${ }^{14} \mathrm{C}$ dates, the same time-line corresponding to various sedimentary environments across the shelf edge. The ${ }^{14} \mathrm{C}$ dates are summarized in Table 1.

Fig. 10: Chirp seismic section, lithology, carbonate content, density and sonic velocity along core MD99-2349, located at $128 \mathrm{~m}$ water depth (position in Fig. 4). This core sampled units U147, U151, and U152, corresponding to a time span estimated to $21 \mathrm{kyr}$ (from 41 to $20 \mathrm{cal}$. kyr BP; see Table1 and Fig. 10). The major facies corresponds to alternating millimetric to centimetric silty clay and silt laminae, with intervals where fine to medium sand beds are more abundant. The base of sandy or silty beds is sharp or even erosional, and they display a clear fining upward trend. Note the change in density and sonic velocity below D65 that corresponds to higher sand content (because of increased cascading of cold water during Heinrich Event 2).

Fig. 11: Scenario for sedimentation on the Bourcart-Hérault interfluve during the LGM "turnaround". This synthetic NW-SE profile is based on seismic interpretation, lithological and chronological data. A) Evolution from $>46$ to 28 cal. $k y r$ BP: this time interval corresponds to a general decrease of relative sea-level and to the end of deposition of U147. Around $41 \mathrm{cal}$. kyr BP, rsl is estimated between 45 and $65 \mathrm{~m}$. The best estimate of the interval encompassed by the erosional surface D63 is 41 to 28 cal. kyr BP. This interval corresponds 
to a major sea-level fall. B) Evolution from 28 to 20 cal. $k y r ~ B P$ : this period is interpreted as a phase of stillstand or very slow decrease of sea-level, followed by the onset of renewed sealevel fall (recorded by units U151 and U152). The cementation of beach rocks at $90 \mathrm{~m}$ water depth occurred at about 21 cal. kyr BP. C) Evolution from 20 to 15 cal. kyr BP. The deposition of seismic unit U154 corresponds to the period of "turnaround" of relative sealevel. Only the fine-grained distal component of the LGM shoreface was preserved, below $140 \mathrm{~m}$ water depth. The lowest sea-level is estimated to be at least $110-115 \mathrm{~m}$ and the onset of rsl rise between 18 and 17 cal. kyr BP. A slow down of the transgression, between 17 and 15.9 cal. kyr BP, is marked by a bathymetric step at $98-105 \mathrm{~m}$. This period corresponds to the onset of deposition of thin transgressive sand bodies on the outer shelf (U155).

Table 1: Summary of the dated samples used for this study. Absolute dates were obtained with accelerator mass spectrometer (AMS) ${ }^{14} \mathrm{C}$ dating of well-preserved shells and microfauna. AMS measurements were made at Lawrence Livermore National Laboratory (LLNL), and at Poznan Radiocarbon Laboratory (PRL). The conventional radiocarbon datings were done by "Centre de datation par le radiocarbone - Université Claude Bernard Lyon1" (Ly) and "Bureau de Recherches Géologiques et Minières" (BRGM). The ages reported herein are $\delta^{13} \mathrm{C}$-normalised conventional ${ }^{14} \mathrm{C}$ years, corrected for an assumed air-sea reservoir effect of -400 years, and then converted into calibrated ages using the Cal v4.4 version (marine98.14c; Stuiver et al., 1998), and the Glacial polynomial (Bard et al., 1998). 


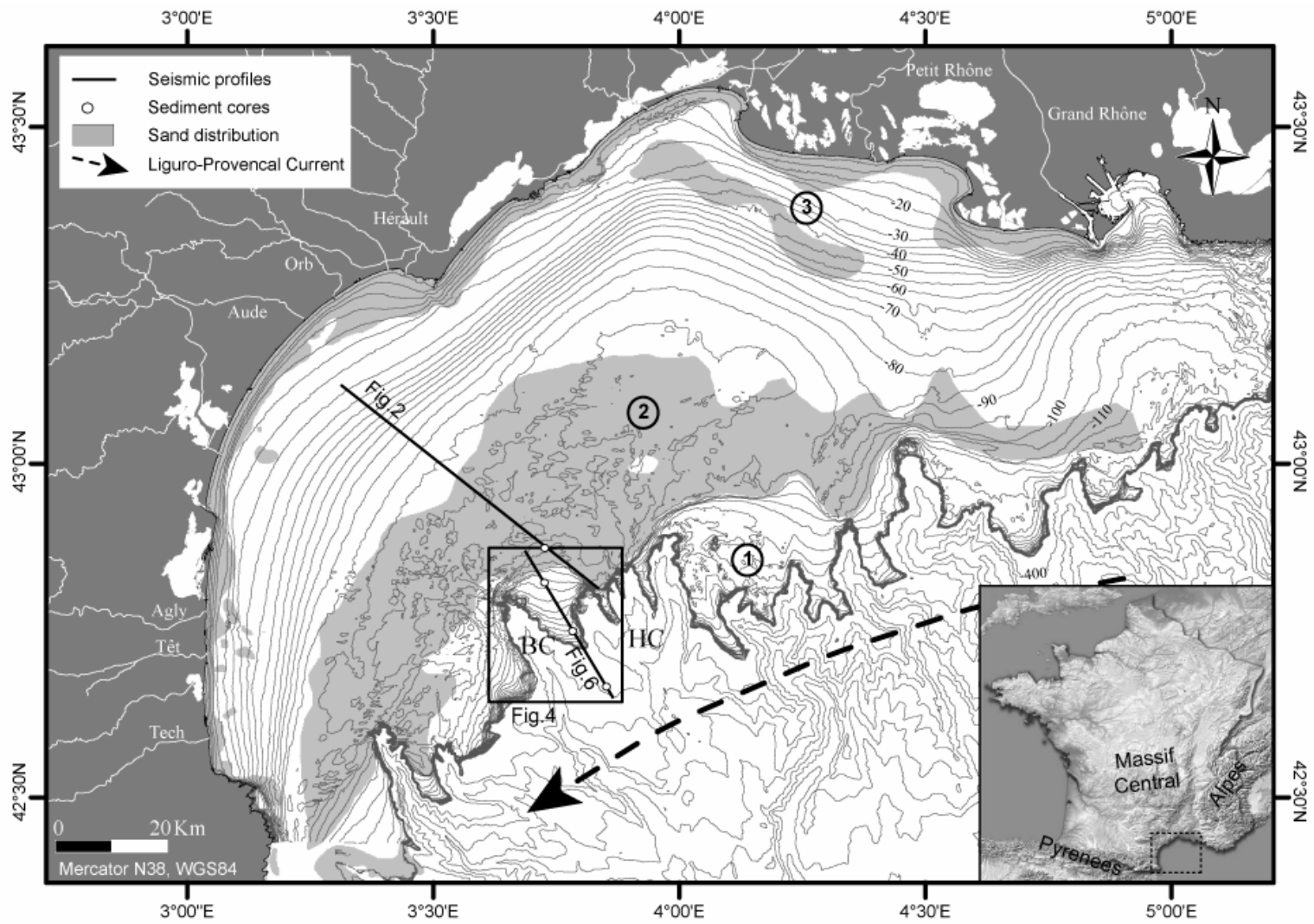

Figure.1 - Jouet et al. (2006) 


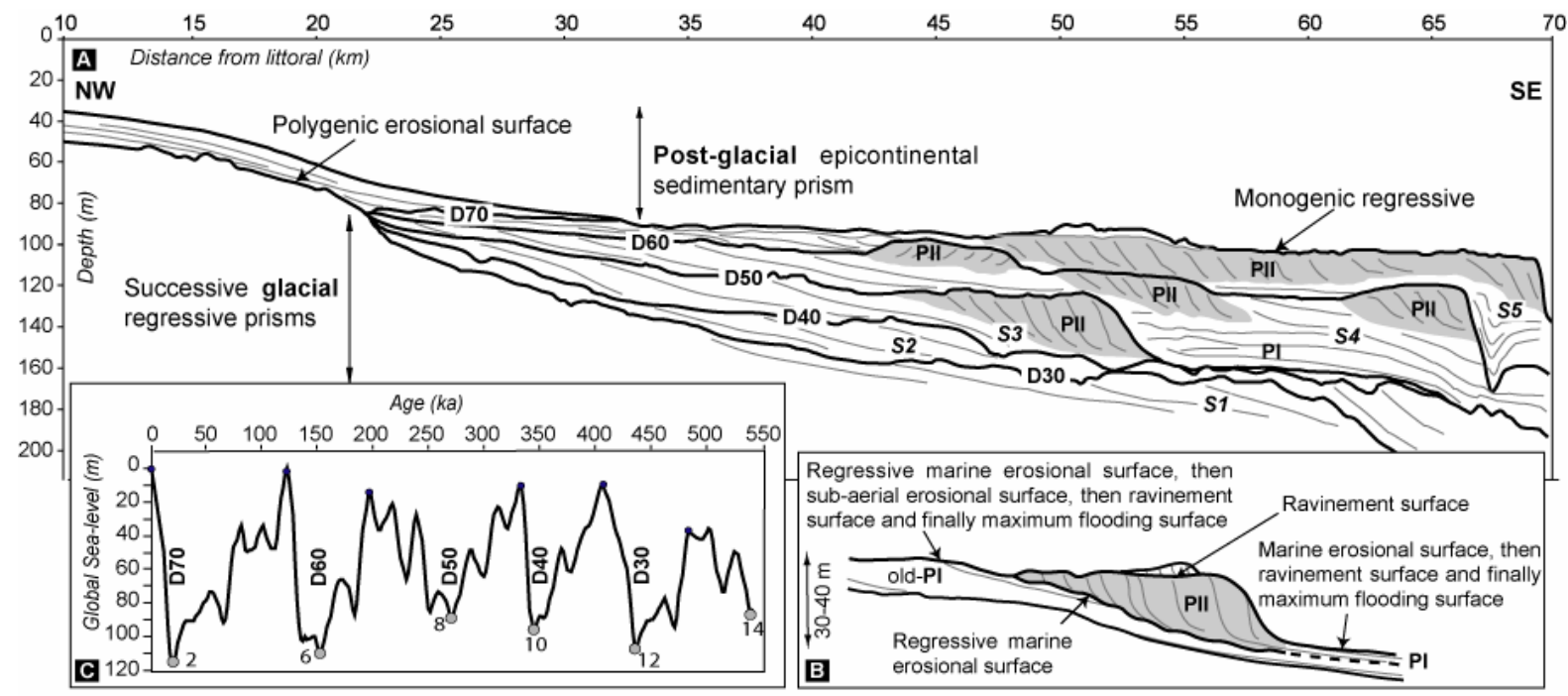

Figure.2 - Jouet et al. (2006) 


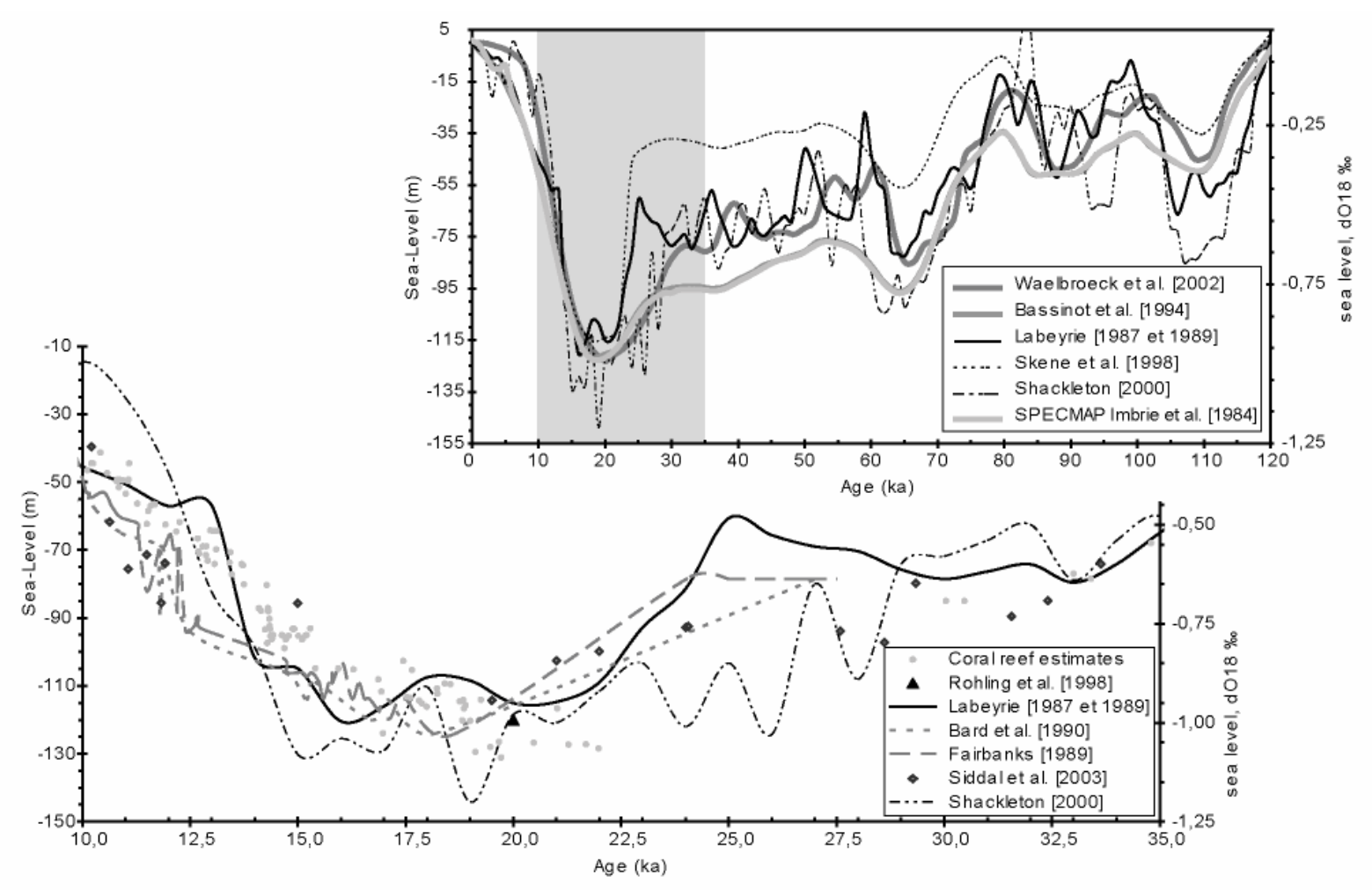

Figure.3 - Jouet et al. (2006) 


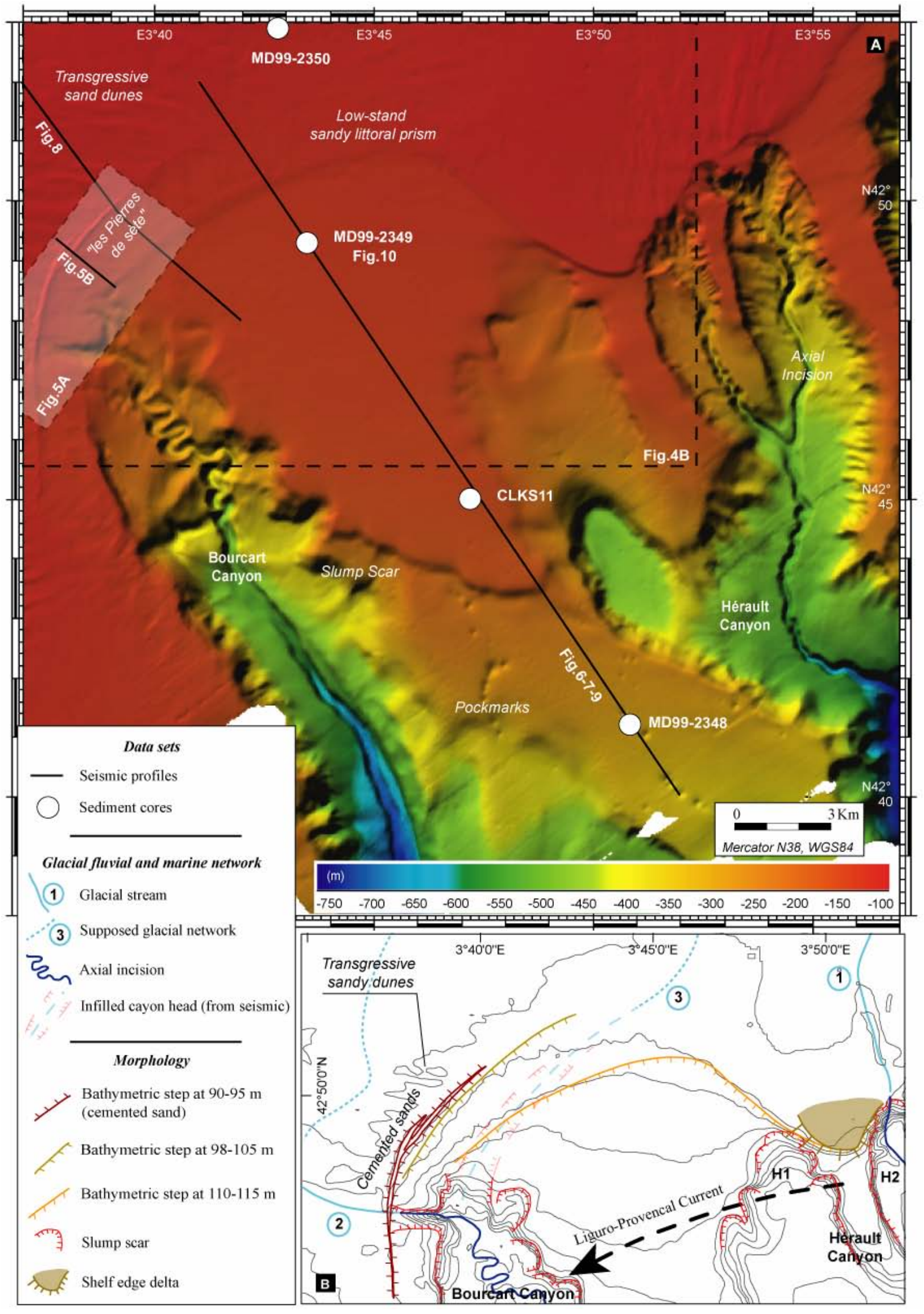

Figure.4 - Jouet et al. (2006) 


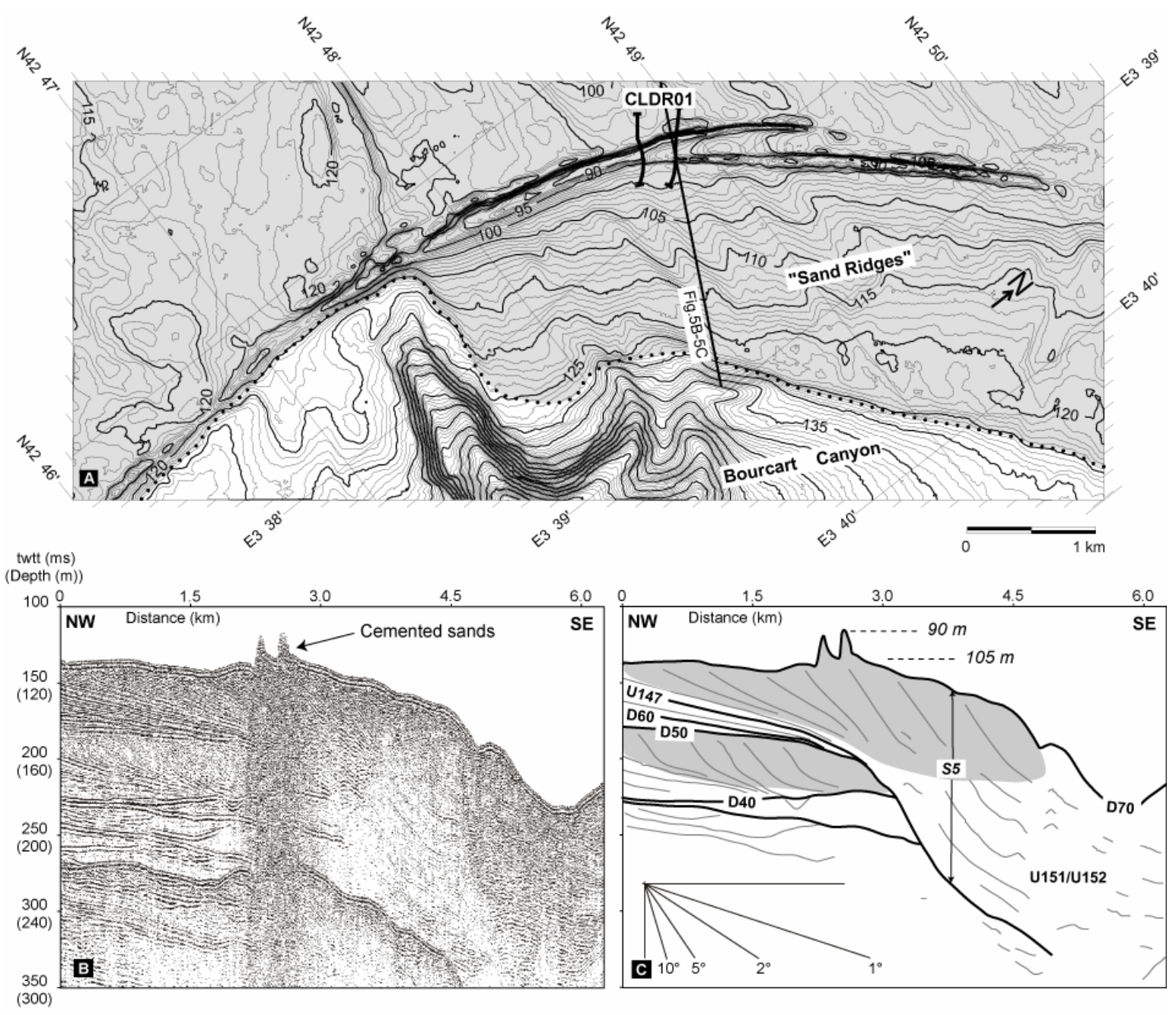

Figure.5 - Jouet et al. (2006) 

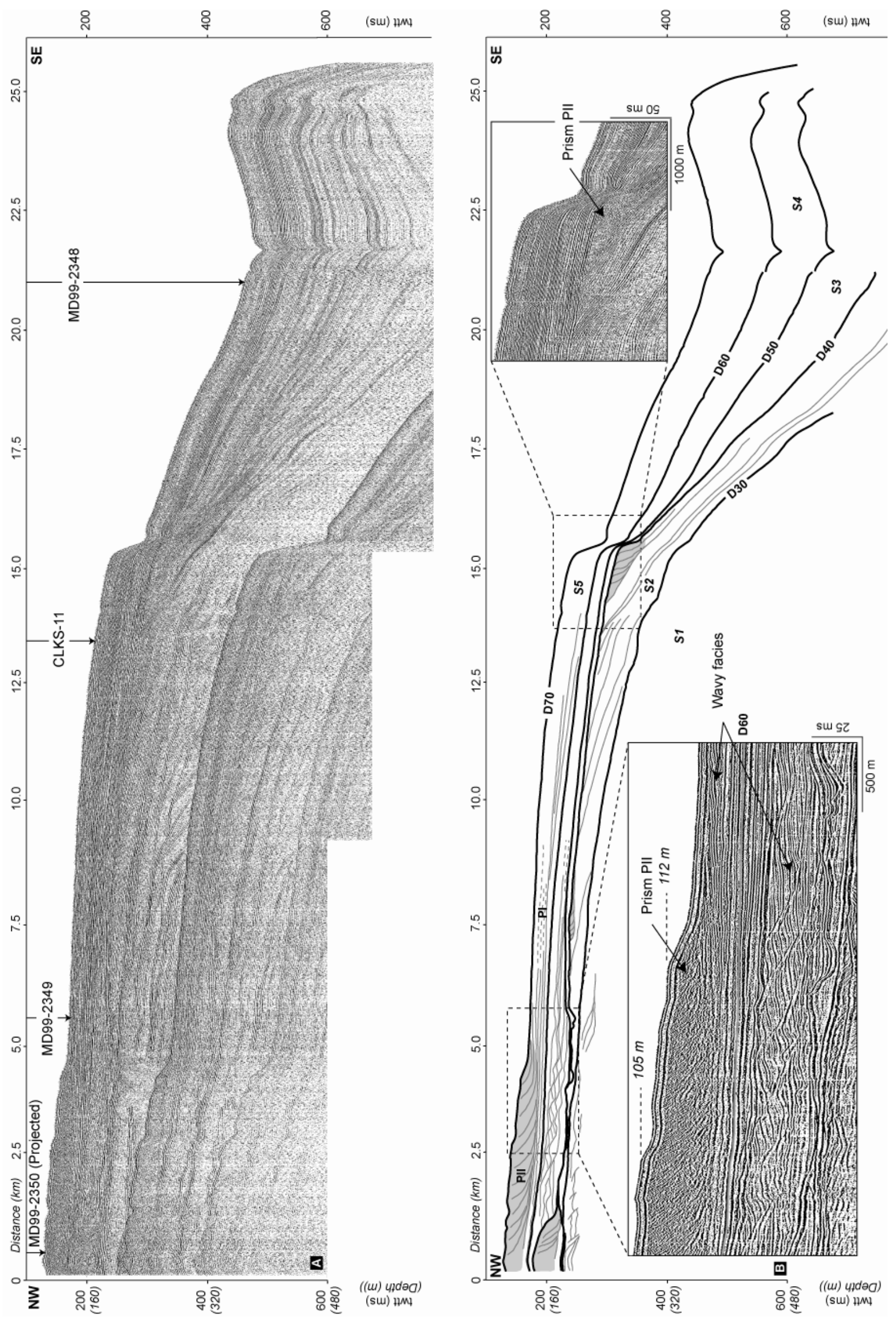

Figure.6 - Jouet et al. (2006) 


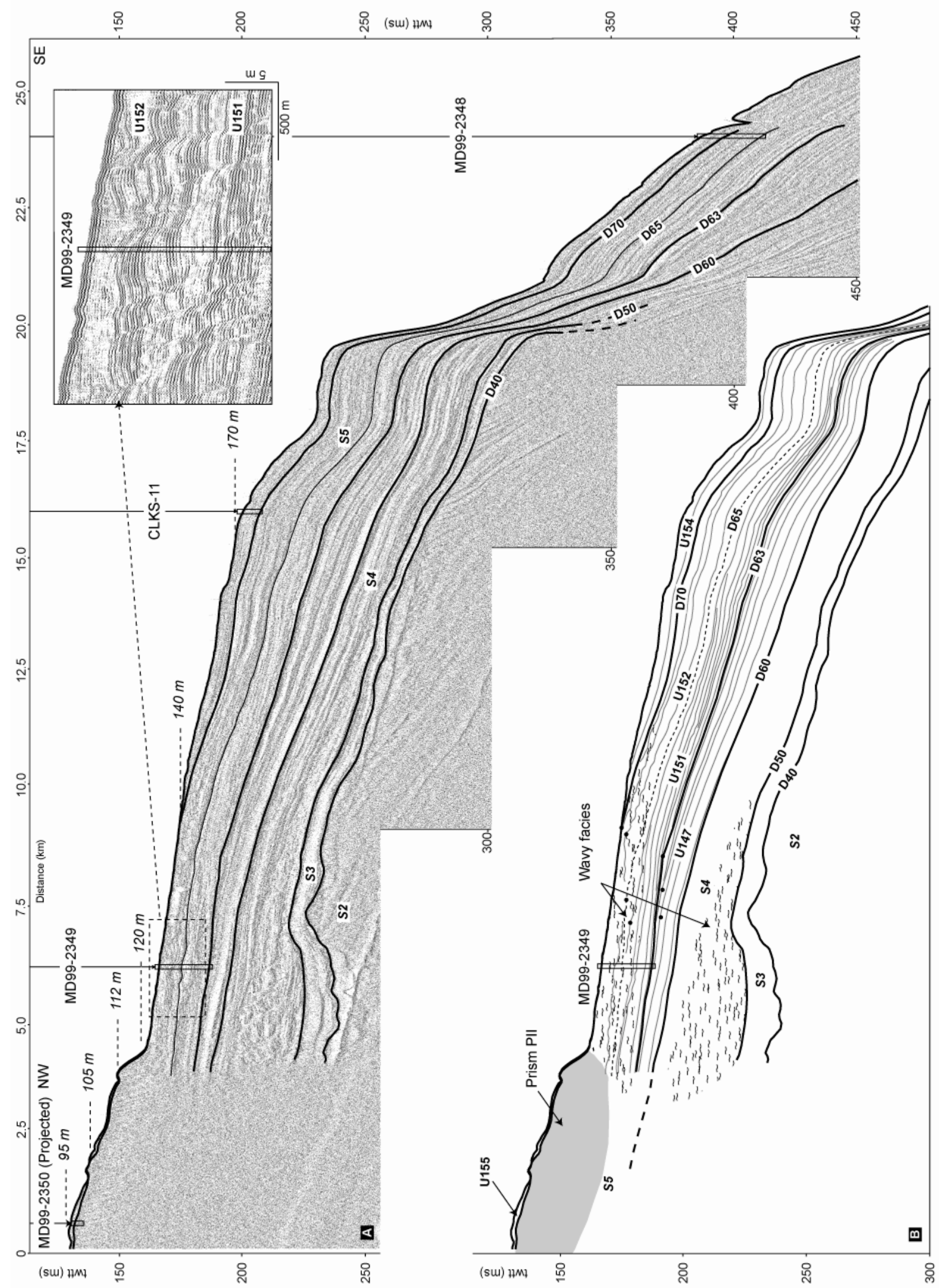

Figure.7 - Jouet et al. (2006) 


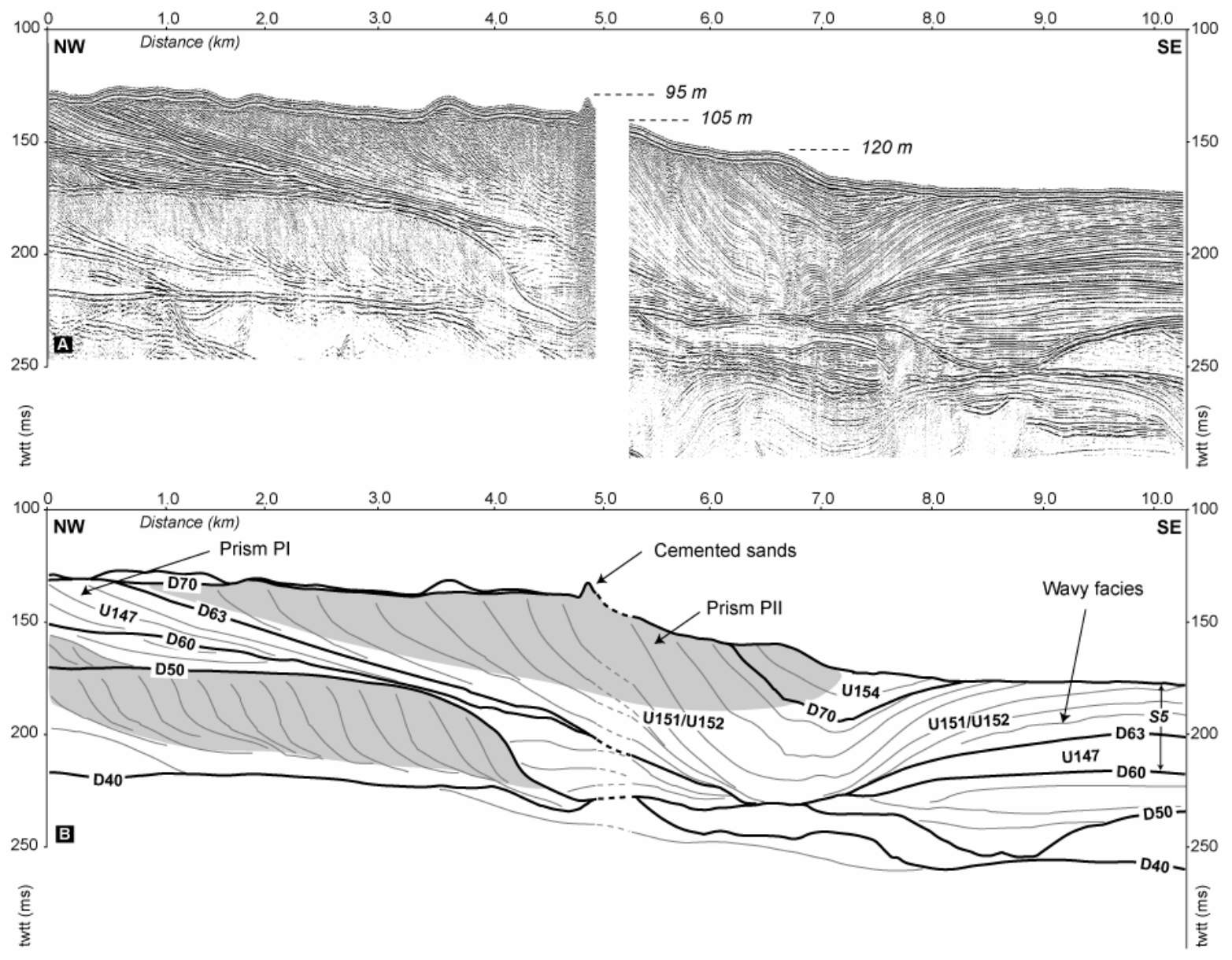

Figure.8 - Jouet et al. (2006) 


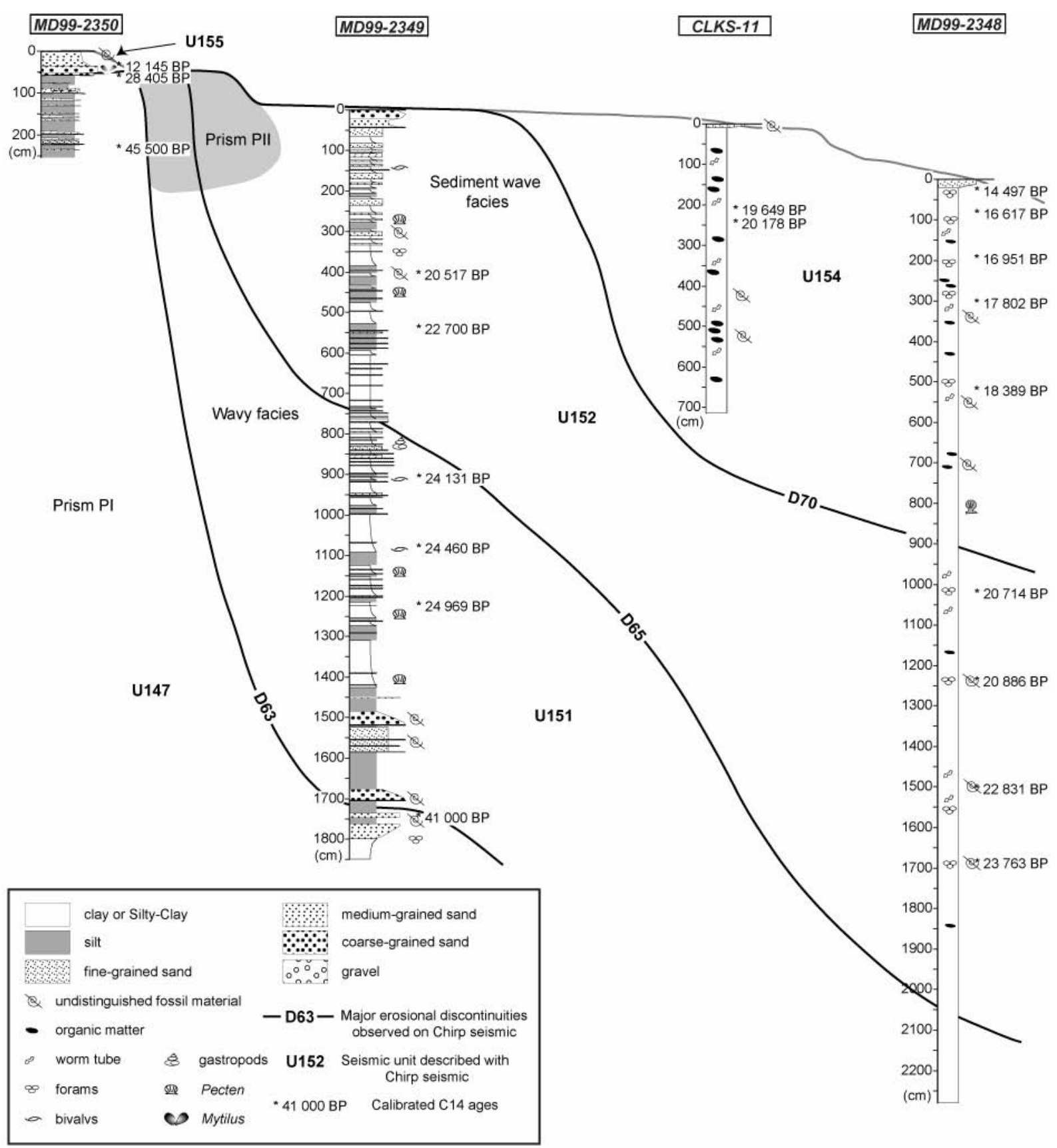

Figure.9 - Jouet et al. (2006) 


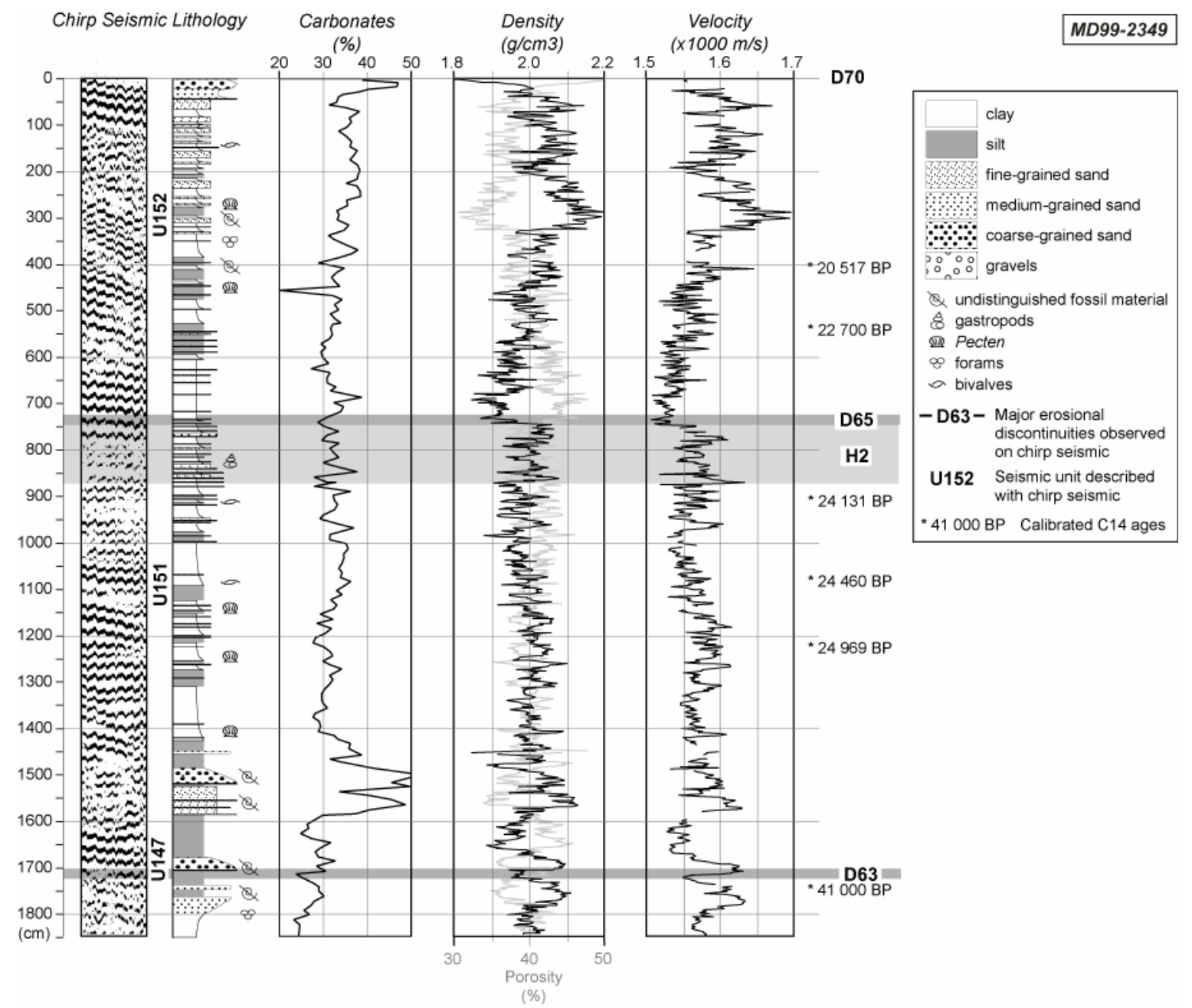

Figure.10 - Jouet et al. (2006) 

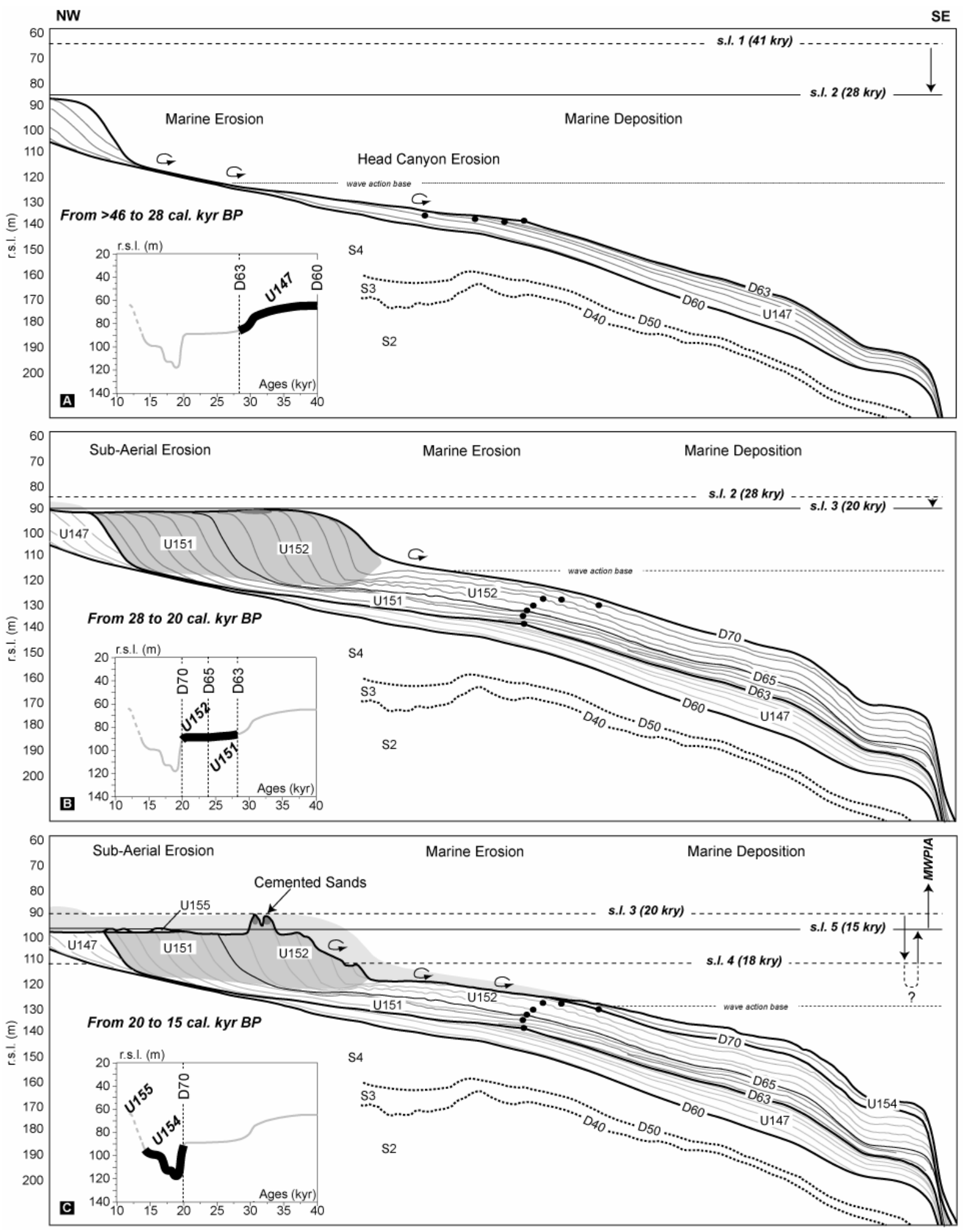

Figure.11 - Jouet et al. (2006) 


\begin{tabular}{|c|c|c|c|c|c|c|}
\hline Depth $(\mathrm{cm})$ & Material & Laboratory \# & $\begin{array}{c}\text { Dating } \\
\text { Technique }\end{array}$ & $\begin{array}{c}\text { Coorected C14 Ages } \\
\text { (years B.P.) }\end{array}$ & Calibrated Age (years B.P.) & Calibration reference \\
\hline \multicolumn{2}{|r|}{ MD99-2350 } & & \multicolumn{4}{|c|}{ Depth : 2,57 mbsf - Water Depth : 98 metres - Location : $42,91067 \mathrm{~N}-003,67733 \mathrm{E}$} \\
\hline 43 & Shell & Ly-11901 & Conventional & $10315+/-60$ & $\begin{array}{l}1683-11891(0,381) \\
11901-12145(0,511)\end{array}$ & Stuiver et al. (1998) \\
\hline $53-54$ & Mytilus spp. & LLNL-98906 & AMS & $23770+/-140$ & $28405(28244-28565)$ & Bard et al. (1998) \\
\hline 240 & Chlamys opercularis & Poz-7860 & AMS & $39800+/-800$ & $45549(44707-46386)$ & Bard et al. (1998) \\
\hline \multicolumn{2}{|r|}{ "Pierres de Setes" CLDR9701 } & & \multicolumn{4}{|c|}{ Depth : Sea floor - Water Depth : 95 - 108 metres - Location : North of Bourcart canyon } \\
\hline 0 & & Ly-91146 & Conventional & $13220+/-130$ & 15499-16071 (1) & Stuiver et al. (1998) \\
\hline 0 & & Ly-91145 & Conventional & $17780+/-170$ & 20645-21403 (1) & Stuiver et al. (1998) \\
\hline 0 & & Ly-9987 & Conventional & $17385+/-240$ & 20148-20991 (1) & Stuiver et al. (1998) \\
\hline \multicolumn{2}{|r|}{ MD99-2349 } & & \multicolumn{4}{|c|}{ Depth : 18,62 mbsf-Water Depth : 128 metres - Location : $42,82117 N-003,72383 E$} \\
\hline 397 & Benthic Foraminifera + Ostracods & Poz-7851 & AMS & $17340+/-90$ & 20183-20852 (1) & Stuiver et al. (1998) \\
\hline $535-538$ & Artica Islandica & Ly-11900 & Conventional & $19235+/-150$ & 22294-23104 (1) & Stuiver et al. (1998) \\
\hline 902 & Cyclichna Spp. & Poz-7852 & AMS & $20570+/-100$ & $24131(24014-24247)$ & Bard et al. (1998) \\
\hline 1074 & Corbula Gibba & LLNL-96163 & AMS & $20750+/-70$ & $24460(24376-24539)$ & Bard et al. (1998) \\
\hline 1218 & Nucula Spp. & Poz-7854 & AMS & $21190+/-100$ & $24969(24853-25085)$ & Bard et al. (1998) \\
\hline $1736-1738$ & Foraminifera Spp. & LLNL-96165 & AMS & $35500+/-800$ & 40979 (40117-41838) & Bard et al. (1998) \\
\hline \multicolumn{3}{|c|}{ CLKS-11 (Rabineau, 2001) } & \multicolumn{4}{|c|}{ Depth : 7,04 mbsf-Water Depth : 157 metres - Location : $42,74983 \mathrm{~N}-003,78267 \mathrm{E}$} \\
\hline 216-219 & Serpulid tubes & LYON-803 & Conventional & $16585+/-110$ & $19318-19980(1)$ & Stuiver et al. (1998) \\
\hline $236-239$ & Serpulid tubes & LYON-804 & Conventional & $17045+/-100$ & $19844-20513(1)$ & Stuiver et al. (1998) \\
\hline \multicolumn{3}{|c|}{ MD99-2348 } & \multicolumn{4}{|c|}{ Depth : 22,77 mbsf-Water Depth : 296 metres - Location : $42,69300 \mathrm{~N}-003,84167 \mathrm{E}$} \\
\hline 25 & nc. & Univ-Salam. & AMS & 12620 & 14497 & Stuiver et al. (1998) \\
\hline 80 & Foraminifera spp. & LLNL-108010 & AMS & $13950+/-60$ & $16377-16857(1)$ & Stuiver et al. (1998) \\
\hline 190 & Foraminifera spp. & LLNL-108011 & AMS & $14240+/-60$ & $16704-17197(1)$ & Stuiver et al. (1998) \\
\hline 300 & Foraminifera spp. & LLNL-108012 & AMS & $14980+/-70$ & $17531-18074$ (1) & Stuiver et al. (1998) \\
\hline 518 & Foraminifera spp. & LLNL-108014 & AMS & $15490+/-70$ & $18101-18677(1)$ & Stuiver et al. (1998) \\
\hline 1018 & Foraminifera spp. & LLNL-108015 & AMS & $17510+/-80$ & 20380-21047 (1) & Stuiver et al. (1998) \\
\hline 1231 & nc. & Univ-Salam. & AMS & 17660 & 20886 & Stuiver et al. (1998) \\
\hline 1498 & Foraminifera spp. & LLNL-108016 & AMS & $19350+/-90$ & $22447-23216(1)$ & Stuiver et al. (1998) \\
\hline $1680-1681$ & Bulk Foraminifera spp. & LLNL-77703 & AMS & $20160+/-80$ & $23763(23358-24193)$ & Bard et al. (1998) \\
\hline
\end{tabular}

Table.1 - Jouet et al. (2006) 